\title{
Bibliography of Technology for Germfree Animal Research
}

\author{
Working Group of Bibliography Compilation of \\ Germfree Animal Technology*
}

\author{
Kazuyoshi Maejima \\ Tomotari Mitsuoka \\ Shigeo Namioka \\ Tatsuji Nomura \\ Yoshio Tajima \\ Tsutomu Yoshida
}

\author{
Keio University School of Medicine \\ The Institute of Physical and Chemical Research \\ Faculty of Veterinary Medicine, Hokkaido University \\ Central Institute for Experimental Animals \\ Nippon Veterinary and Zootechnical College \\ Tachikawa College of Tokyo
}

The literature in this bibliography consists of the available technical reports concerning germfree mammalian and avian research classified as follows (Abstracts and brief descriptions with no data were excluded): 1. Isolators, 2. Diets, 3. Sterilization, 4. Obtaining germfree infants and hand-rearing, 5. Animal care, management and transportation, 6. Experimental method, 7. Sterility tests and contamination, 8. Operating rooms and patient isolators. The references either missing or after 1974 will be published in this journals in a series of supplements.-Exp. Animals, 24 (4),229-253, 1974.

\section{無菌動物研究に関連する技術の文献集}

無菌生物学に関する文献は B. A. Teah の献身的な 努力によって集められ，すでに 2649 篇が 7 冊の Bibliography of Germfree Research に収められ，無菌 生物研究の必須資料となっている。しかし, 文献をでき るだけ広く集めようとしたためと思われるが，ての Bibliography には講演要旨や簡単な解説記事も収録され， 文献を手にして失望することあある。また，日本では入 手困難なあのがある反面，わが国の論文が必ずしも十分 に採られていないという不満がないわけではない。

そこで, 引用に值しかつ引用しやすい文献集をつくる ことは無䭾でないと考え, 金内長司 (理研)，柏崎守(家 衛試)，山中聖敬（実中研）の協力をえて作業をすすめ てきた。乙の場合, 無菌生物学のすべてにわたる文献が 集められるにこしたことはないが，われわれの力の及ぶ ところではなく，たとえ実行されたとしても，できあが ったあのは Teah の Bibliography と質的に同じとな ろう。むしろ, 実験動物学という領域を意識して Technology に重点をおき，無菌動物に関する技術の文献を 収録することが妥当と考えられた。

実際の作業は，われわれがあっている 1973 年までの 文献カードを集め，下記規準によって取捨選択した。

1. 飼育器具

2. 飼料組成および滅菌による変化
3. 滅菌

4. 無菌仔摘出および哺育

5. 飼育管理および輸送

6. 実験手技

7. 無菌試験および污染

8. 手術室および患者用アイソレータ

対象生物は哺乳類と鳥類に限り, 変温動物や植物の文 献は除外したが, 技術的に共通するところが多く, 最近 さかんに検討されている無菌手術室や患者用アイソレー タに関するものは収録した。そして，ててでは技術の文 献として有用なもののみ採り, 具体的なデータを欠くあ の, 講演要旨,きわめて短かい記述などは除いた。また, ここに収められた文献は，われわれのうちのだれかによ って目が通されて拈り, その大部分は日本で入手可能で ある。

いうまであなく,ての文献集には収録もれがあろうし， 1974年度分は加えられていない。不備を補いつつ定期的 に Supplement をつくり, 実験動物誌上に公表していく 予定である。収録あれや気づいた点, あるいは所在のわ

*Office: c/o K. Maejima, Laboratory Animal Center, Keio University School of Medicine, Shinjuku, Tokyo 160, Japan. 
からない文献については, 東京都新宿区信濃町 35, 7160 , 慶応義塾大学医学部実験動物センター前島一淑まで連絡 されたい。なお，この文献集が外国であ利用されること を期待したため, Teah の Bibliography との関連を考 慮し, 文献の記載形式については本誌規定のそれに必ず しあ従っていない。

\section{無菌動物技術文献集編集会}

前島一淑（慶応義塾大学医学部）

光岡知足 (理化学研究所)

波岡茂郎 (北海道大学獣医学部)

野村達次 (実験動物中央研究所)

田嶋嘉雄 (日本獣医畜産大学)

吉田 勉(都立立川短期大学)

この文献集を編集するにあたり，日本クレア株式会社 の援助をうけたことを明記し，謝意を表する。

1 Aarons, T. and Hill, R. : Irradiated laboratory animal feed production. Proc. Anim. Care Panel, '8, 155, 1958.

2 Abraham, J., Adrian, J., Calet, C., CharletLery, G., Delort-Laval, J., Guillaume, J., Gutton, M., Lougnon, J., Rérat, A. and Zelter, S. $Z$. : Traitement thermique et qualité des proteines du soja VIII Sensibilité de trois espèces animales (rat, porc, poulet) et de divers tests biochemiques à l'intensité de la cuisson du tourteau. Ann. Zootech., 20, 75, 1971.

3 Abrams, G. D. and Bishop, J. E. : Germfree techniques in experimental pathology: A survay of the morphologic changes in, and the research potential of, the germfree guinea pigs. Univ. Michigan Med. Bull., 27, 136, 1961.

4 Abrams, G. D., Bishop, J. E., Appleman, H. D. and French, A. J. : Development of a laboratory for germfree research in the Department of Pathology. Univ. Michigan Med. Bull., 26, 165, 1960.

5 Adamiker, D. : Pasteurisation bzw Sterilisation von SPF-Versuchstierfutter mit Hilfe ionisierender Strahlen. Z. Versuchstierk., 10, 175. 1968.

6 赤沢喜三郎 (Akazawa, K.) : 鶏雛の無菌飼育に依 る発育及び其の腸内菌叢 (Growth of chickens under germfree condition and their intestinal flora). 千葉医会誌 (Chiba Igk. Z.)， 20，1884， 1942.

7 Alder, V. G. and Gillespie, W. A. : Automatic high pre-vacuum steam sterilization for surgical dressings and gloves. J. Clin. Path., 10,
$299,1957$.

8 Alexander, T. J. L. and Lysons, R. J. : Observations on rearing gnotobiotic lambs. Brit. Vet. J., 127, 349, 1971.

9 Alexander, T. J. L., Lysons, R. J., Elliott, L. M. and Wellstead, P. D. : Techniques for rearing gnotobiotic lambs. Lab. Anim., 7, 239, 1973.

10 Allen, D. W. and Sarma, P. S. : Identification and localization of avian leukosis group-specific antigen within "leukosis-free" chick embryos. Virology, 48, 624, 1972.

11 Allen, R. C., Meier, H. and Hoag, W. G. : Ethylene glycol produced by ethylene oxide sterilization and its effect on blood-clotting factors in an inbred strain of mice. Nature, 193, 387. 1962.

12 Alpert, S., Salzman, T., Sullivan, C., Palmer, C. and Levenson, S. M.: Use of a surgical isolator for major surgery: Influence on wound contamination and postoperative wound infections. In Germfree Research Biological Effect of Gnotobiotic Environments, edited by Heneghan. Academic Press, N.Y. \& London (1973).

13 Amtower, W. C. and Calhoon, J. R. : A betapropiolactone sterilized milk formula for specific pathogen-free pigs. Lab. Anim. Care, 14, 382,1964 .

14 Anderson, J. C.: Germicide for sterilising the surface of eggs in gnotobiology. J. Med. Microb., 2, 379, 1969.

15 Appel, K. R., Busse, H., Schulz, K. D. and Wilk, W. : Beitrag zur Handaufzucht von Gnotobiotischen und SPF-Kaninchen. Z. Versuchstierk., 13, 282, 1971.

16 Ashe, W. K., Scherp, H. W. and Fitzgerald, R. J. : Previously unrecognized virus from submaxillary glands of gnotobiotic and conventional rats. J. Bact., 90, 1719, 1965.

17 Baker, D. E. J.: Methods of construction and use of a disposable device for economically transporting small gnotobiotes. Lab. Anim. Care, 15, 432, 1965.

18 Bakerman, H., Romine, M., Schricker, J. A., Takahashi, S. M. and Mickelsen, O. : Stability of certain B vitamins exposed to ethylene oxide in the presence of choline chloride. J. 
Agric. Food Chem., 4, 956, 1956.

19 Balzam, N.: Elevage aseptiques des animaux I Appareillages et methods. Ann. Phys., 13, 370 1973.

20 Barnes, R. D.: Gnotobiotic man. Adv. Exp. Med. Biol., 3, 45, 1969.

21 Barrett, Jr., J. P.: Sterilizing agents for Lobund flexible film apparatus. Proc. Anim. Care Panel, 9, 127, 1959.

22 Beall, J. R., Torning, F. E. and Runkle, R. S. : A laminar flow system for animal maintenance. Lab. Anim. Sci., 21, 206, 1971.

23 Bengson, M. H. and Thomae, F. W. : Controlling the hazards of biological and particulate contamination within manned space craft. J. Am. Assoc. Contamination Control, 4, 9, 1965.

24 Bernard, E. : Methods and problems concerned with hand-rearing rabbits. J. Anim. Tech. Assoc., 13, 35, 1962.

25 Betts, A. O. : Gnotobiotic animals and some of their use. The future of the defined laboratory animal. Carworth Europe Collected Papers, 1, 65, 1967.

26 Betts, A. O., Lamont, P. H. and Littleworth, M. C. G.: The production by hysterectomy of pathogen-free colostrum-deprived pigs and the foundation of a minimal-disease herd. Vet. Rec., 72, 461, 1960.

27 Blackmore, D. K. : Hygiene. In The UFAW Handbook on the Care and Management of Laboratory Animals, 4th ed. Churchill Livingstone, Edinburgh \& London (1972).

28 Bleby, J. : Housing of disease-free animals. In Laboratory Animal Symposia 1 The Design and Function of Laboratory Animal Houses, edited by Hare \& O'Donoghue. Laboratory Animal Ltd., London (1968).

29 Bleby, J. : Disease-free (SPF) animals. In The UFAW Handbook on the Care and Management of Laboratory Animals, 4th ed. Churchill Livingstone, Edinburgh \& London (1972). a specific pathogen free cat (Felis catus) colony. J. Small Anim. Prac., 10, 237, 1969.

31 Bodey, G. P. : Laminar air flow unit for patients undergoing cancer chemotherapy. Adv. Exp. Med. Biol., 3, 19, 1969.
32 Bodey, G. P. and Johnston, D. : Microbiological evaluation of protected environments during patient occupancy. Appl. Microb., 22, 828, 1971. Bohner, H. J. and Miller, C. E. : Studies on rearing the hamster germfree. In Germfree Research Biological Effect of Gnotobiotic Environments, edited by Heneghan. Academic Press, N. Y. \& London (1973).

34 Bowe, J. H. : Modern apparatus for sterilization. Pharm. J., 174, 11, 1955.

35 Brand, H. G., Kundzins, W., Reese, W. H. and Kerber, W. T.: The gnotobiotic primate. Procedures involving adaptation and maintenance in a germfree environment. Lab. Anim. Care, 13, 557, 1963.

36 Brewer, J. H. : Antibacterial effects of the organic mercurial compounds, with special reference to their use as germicides for the sterilization of surgical and dental instruments. J. Am. Med. Assoc., 112, 2009, 1939.

37 Bromont, P. : Technique d'élevage du lapin gnotobiotique. Rec. Méd. Vet., 154, 221, 1968.

38 Burton, H., Ford, J., Perkin, A. G., Porter, J. W., Scott, K. J., Thompson, S. Y., Toothill, J. and Edwards-Webb, J. D. : Comparison of milks processed by the direct and indirect methods of ultra-high-temperature sterilization 4 The vitamin composition of milks sterilized by different processes. J. Dairy Res., 37, 529, 1970.

39 Calet, C. and Guillaume, J. : Traitement thermique et qualité des proteines du soja VI Efficacité comparée pour la croissance du poussin de tourteaux préparés dans différentes conditions. Ann. Zootech., 20, 61, 1971.

40 Calhoon, J. R. and Matthews, P. J. : A method for initiating a colony of specific pathogen-free guinea pigs. Lab. Anim. Care, 14, 388, 1964.

41 Carter, D. and Einheber, A. : A system for providing surgical anesthesia for germfree rodents. J. Appl. Phys., 20, 571, 1965.

42 Casillo, S. and Blackmore, D. K.: Uterine infections caused by bacteria and mycoplasma in mice and rats. J. Comp. Path., 82, 477, 1972.

43 Chakhava, O. V., Zenkevich, M. V. and Zazenkind, T. I.: Some results with diets de- 
signed for rearing germfree guinea pigs. In Advances in Germfree Research and Gnotobiology, edited by Miyakawa \& Luckey. Iliffe Book, London-Chemical Rubber, Ohio (1968).

44 Chappel, C. I. and MacQueen, K. F. : Effect of gamma irradiation on vitamin content of enriched flour. Food Irrad., 10, 8, 1970.

45 Charles, R. T., Stevenson, D. E. and Walker, A. I. T. : The sterilization of laboratory animal diet by ethylene oxide. Lab. Anim. Care, 15, $321,1965$.

46 Charles, R. T. and Walker, A. I. T.: The use of the ethylene oxide for the sterilization of laboratory animals foodstuffs and bedding. J. Anim. Tech. Assoc., 15, 44, 1964.

47 Christie, B. R. : Hysterectomy produced artificially reared pigs and their possible use in the control of disease. Aust. Vet. J., 39, 148, 1963. Coates, M. E. (Editor) : The Germfree Animal in Research. Academic Press, N. Y. \& London (1968).

49 Coates, M. E. : Animal production and rearing III Chickens and quail. In The Germfree Animal in Research, edited by Coates. Academic Press, N. Y. \& London (1968).

50 Coates, M. E.: Germfree animals. In The I. A. T. Manual of Laboratory Animal Practice and Techniques, 2nd ed., edited by Short \& Woodnott. Crosby Lockwood, London (1969).

51 Coates, M. E.: The sterilization of laboratory animal diets. In Nutrition and Disease in Experimental Animals, edited by Tavernor. Baillière, Tindall \& Cassell, London (1970).

52 Coates, M. E., Ford, J. E., Gregory, M. E. and Thompson, S. Y. : Effects of gamma-irradiation on the vitamin content of diets for laboratory animals. Lab. Anim., 3, 39, 1969.

53 Coates, M. E., Fuller, R., Harrison, G. F., Lev, M. and Suffolk, S. F.: A comparison of the growth of chicks in the Gustafsson germfree apparatus and in a conventional environment, with and without dietary supplements of penicillin. Brit. J. Nutr., 17, 141, 1963.

54 Coates, M. E., Gregory, M. E. and Thompson, S. Y. : The composition of rabbit's milk. Brit. J. Nutr., 18, 583, 1964.

55 Coates, M. E., Hewitt, D. and Golob, P.: A

comparison of the effects of raw and heated soya-bean meal in diets for germfree and conventional chicks. Brit. J. Nutr., 24, 213, 1970.

56 allergy in infant germfree rabbits. Nature, 213, 307, 1967.

57 Cohendy, M. and Wollman, E. : Experiences sur la vie sans microbes. Elevage aseptique de cobayes. C. R. Acad. Sci., 158, 1283, 1914.

58 Cook, R. and Bishop, A. : Results of bacteriological testing of germfree laboratory animals. Lab. Anim., 3, 79, 1969.

59 Cook, R. and Crook. L. J.: Rigid polythene containers for the radiation sterilization of supplies for germfree animal isolators. Lab. Anim., 5, 213, 1971.

60 Cook, R. and Dorman, R. G. : Anaesthesia of germfree rabbits and rats with halothane. Lab. Anim., 3, 101, 1969.

61 Coriell, L. I., McGarrity, G. J. and Blakemore, W. S. : Biomedical applications of laminar airflow. In Germfree Research Biological Effect of Gnotobiotic Environments, edited by Heneghan. Academic Press, N. Y. \& London (1973).

62 Cumming, C. N. W. and Baker, D. E. J. : The use of the flexible film isolator in the large scale production of small laboratory rodents I Modifications of pilot equipment and production statistics. Lab. Anim. Care, 13 (Part 2), $624,1963$.

63 Cumming, C. N. W. and Baker, D. E. J. : A large flexible film isolator and its use in the production of gnotobiotes. In Advances in Germfree Research and Gnotobiology, edited by Miyakawa \& Luckey. Iliffe Book, LondonChemical Rubber, Ohio (1968).

64 Darlow, H. M. : The practical aspects of formaldehyde fumigation. Mon. Bull. Minist. Hlth Lab. Serv., 17, 170, 1958.

65 Darlow, H. M. : The provision of clean air. M. R. C. Collected Papers, 10, 65, 1961.

66 Darmady, E. M., Hughes, K. E. A., Burt, M. M., Freeman, B. M. and Powell, D. B. : Radiation sterilization. J. Clin. Path., 14, 55, 1961.

67 Darmady, E. M., Hughes, K. E. A. and Jones, J. D. : Thermal death-time of spores in dry heat in relation to sterilization of instru- 
ments and syringes. Lancet, (2), 766, 1958.

68 D., Prince, D. and Tuke, W. : Strilization by dry heat. J. Clin. Path., 14, 38, 1961.

69 Darmady, E. M., Hughes, K. E. A., Jones, J. D. and Tuke, W. : Sterilization by conducted heat. Lancet, (2), 769, 1958.

70 Davery, D. G. : Establishing and maintaining a colony of specific pathogen-free mice, rats and guinea pigs. M. R. C. Collected Papers, 8, 17, 1959.

71 Decker, H. M., Buchanan, L. M., Hall, L. B. and Goddard, K. R. : Air Filtration of Microbial Particles. U. S. Goverment Printing Office, Washington（井上宇市訳：微生物粒子の空 気沪過法, 病院設備, $8(4), 19,1966)$.

72 Decker, H. M., Citek, F. J., Harstad, J. B., Groos, N. H. and Piper, F. J. : Time temperature studies of spore penetration through an electric air sterilizer. Appl. Microb., 2, 33, 1954.

73 Decker, H. M., Geile, F. A., Harstad, J. B. and Groos, N. H.: Spun glass air filters for bacteriological cabinets, animal cages and shaking machine containers. J. Bact., 63, 377, 1952.

74 de Harven, E.: Virus particles in the thymus of conventional and germfree mice. J. Exp. Med., 120, 857, 1964.

75 de Koning, J., van der Waaij, D., Vassen, J., Versprille, A. and Dooren, L. J. : Barrier nursing of an infant in a laminar cross flow bench. Maandschr. Kindergeneesk., 38, 1. 1970.

76 Delort-Laval, J. and Charlet-Lery, G. : Traitement thermique et qualité des proteines du soja V Mesure, par la méthode des bilans, de la valeur biologique de l'azote des tourteaux chez le porcen croissance. Ann. Zootech., 20, 53, 1971.

77 Dietrich, M., Fliedner, T. M. and Heimpel, H. : Isolierbett-System zur Infectionsprophylaxe bei verminderter Resistenz. Deut. Med. Wschr., 94, 1003, 1969.

78 Dietrich, M., Fliedner, T. M. and Krieger, D. : Germfree technology in clinical medicine: Production and maintenance of gnotobiotic states in man. In Germfree Research Biological Ef- fects of Gnotobiotic Environments, edited by Heneghan. Academic Press, N. Y. \& London (1973).

79 Dietrich, M., Meyer, H., Krieger, D., Genscher, A., Fliedner, T, N. and Teller, W. : Development and use of a children plastic isolation system for prevention of infection. Rev. Europ. Etud. Clin. Biol., 17, 488, 1972.

80 Dinsley, M. : Gnotobiotic animals II. In The UFAW Handbook on the Care and Management of Laboratory Animals, 4th ed. Churchill Livingstone, Edinburgh \& London (1972).

81 Done, J. T. : Aseptic delivery and artificial rearing: A technique for disease control in pigs. Vet. Rec., 67, 129, 1955.

82 Edward, A. G., Mills, G. D. and Calhoon, J. R. : Production of colostrum-deprived specific pathogen-free calves. Lab. Anim. Care, 17, 103, 1967.

83 Egan, B. J. : Ancillary equipment for isolators 2 A food transfer unit. Lab. Anim., 7, 33, 1973.

84 Egan, B. J. and Butler, E. J. : Controlled environment systems for experimental animals I A unidirectional air flow brooder for chicks. Lab. Anim., 6, 23, 1972.

85 Egan, B. J. and Butler, E. J. : Controlled environment systems for experimental animals II A unidirectional air flow tent. Lab. Anim., 6, 119, 1972.

86 Enigk, K. and Eckert, J. : Die Desinfektion von Tierausläufen. Zbl. Bakt. I. Orig., 179, 397, 1960.

87 E. O. R. T. C. Gnotobiotic Project Group : Protocol for an evaluative study of the protective effect of isolation systems and decontamination in patients with high susceptibility to infection. Europ. J. Cancer, 8, 367, 1972.

88 Erbersdobler, H. and Dümmer, H. : Untersuchungen zur analytischen und physiologischen Characterisierung der Aminosäurenschädigung durch Hitzebehandlung 3 Untersuchungen an einem überhitzten Magermilchpulver. Z. Tierphys. Tierernähr. Futtermittel., 28, 224, 1971.

89 Erbersdobler, H. and Zucker, H. : Zur Bestimmung von verfügbaren Lysin in Futtermitteln mit Dinitrofluorbenzol. Z. Tierphys. Tierernähr. 
Futtermittel., 19, 244, 1964.

90 Ernst, R. R. and Shull, J. J. : Ethylene oxide gaseous sterilization I Concentration and temperature effects. Appl. Microb., 10, 337, 1962.

91 Ernst, R. R. and Shull, J. J. : Ethylene oxide gaseous sterilization II Influence of method of humidification. Appl. Micob., 10, 342, 1962.

92 江角新一郎 (Ezumi, S.): 除菌と P. V. A. フィ ルター (Filtration of microbes and P. V. A. filter). 空気清浄 (Jap. Air Cleaning Assoc.), 3 (3), 29, 1965.

93 Eyssen, H. : Die Gnotobiologie der Nichtwiederkäuer. In Biologie und Biochemie der Mikrobiellen Verdauung, edited by Gieseckc \& Henderickx. BLV Verlag, München (1973).

94 Ferrando, R., Pantaléon, J. and Fromageot, D. : Etude comparative de la stérilisation classique et de la radiopasteurisation sur un aliment destiné au rat. Ann. Nutr. Alim, 22, 25, 1968.

95 Floyd, M. J. and Pierson, G. : A cheap and effective method of sterilizing animal cages. J. Anim. Tech. Assoc., 10, 124, 1959.

96 Flynn, R. J., Simkins, R. C., Brennan, P. C. and Fritz, T. E. : Uterine infection in mice. $Z$. Versuchstierk., 10, 131, 1968.

97 Foord, N. and Lidwell, O. M. : The control by ventilation of airborne bacterial transfer between hospital patients, and its assessment by means of a particle tracer I An airborne-particle tracer for cross-infection studies. J. Hyg. Camb., 70, 279, 1972.

98 Foster, H. L. : A canned sterile source of water and feed for the breeding and maintenance of gnotobiotic mice. In Advances in Germfree Research and Gnotobiology, edited by Miyakawa \& Luckey. Iliffe Book, London-Chemical Rubber, Ohio (1968).

99 Foster, H. L. : The use of microwave sterilization and pasteurization for barrier-sustained animal colonies. Lab. Anim. Care, 18, 356, 1968.

100 Foster, H. L., Black, C. L. and Pfau, E. S. : A pasteurization process for pelleted diets. Lab. Anim. Care, 14, 373, 1964.

101 Foster, H. L. and Pfau, E. S. : Gnotobiotic animal production at the Charles River Breeding Laboratories, Inc. Lab. Anim. Care, 13
(Part 2), 629, 1963.

102 Freeman, A. (Editorial) : Plastics, gnotobiotes and asepsis. J. Am. Vet. Med. Assoc., 138, 506, 1961.

103 Fuller, R. : The routine microbiological control of germfree isolators. In The Germfree Animal in Research, edited by Coates. Academic Press, N. Y. \& London (1968).

104 古橋正吉 (Furuhashi, M.) : 病院の手術室とバイオ クリーンー-とくに術後感染問題との関連- (Operation room and bioclean). 空気清净(Jap. Air Cleaning Assoc.), 11(2), 1, 1973.

105 Ganaway, J. R., Allen, A. M., Moore, T. D. and Bonner, H. J. : Natural infection of germfree rats with Mycoplasma pulmonis. J. Inf. Dis., 127, 529, 1973.

106 Georgii, A., Lenz, I. and Zobl, H. : Penetration of the placental barrier by the lactate dehydrogenase elevating virus (Riley) and its behavior in mouse embryo cultures following infection in utero. Proc. Soc. Exp. Biol. Med., 117, 322, 1964.

107 Gershenfeld, L. and Davis, D. E. : Effect of peracetic acid on some thermoaciduric bacteria. Am. J. Pharm., 124, 337, 1952.

108 Gilbey, J. G. and Pollard, M. : Search for mycoplasma in germfree leukemic mice. J. Nat. Cancer Inst., 38, 113, 1967.

109 Girard, A. and Mitchell, D. : Production de porcs exempts d'organismes pathogenes (EOPS) primaires et établissement d'un troupeau de porcs EOPS secondaires. Can. J. Comp. Med. Vet. Sci., 26, 279, 1962.

110 Glick, C. A., Gremillion, G. G. and Bodmer, G. A.: Practical methods and problems of steam and chemical sterilization. Proc. Anim. Care Panel, 11, 37, 1961.

111 Glimstedt, G. : Das Leben ohne Bakterien. Sterile Aufziehung von Meerschweinchen. Anat. Anz. Erganz-heft, 75, 79, 1932.

112 Glimstedt, G.:Bakterienfreire Meerschweinchen. Aufzucht, Lebensfähigkeit und Wachstum, nebst Untersuchungen über das lymphatische Gewebe. Acta Path. Microb. Scand., 30 (Suppl.), 1936.

113 Glimstedt, G. : Der Stoffwechsel bakterienfreier Tiere I Allgemeine Methodik. Skand. Arch. 
Phys., 74, 48, 1936.

114 Glimstedt, G. : Der Stoffwechsel bakterienfreier Tiere III Die Gewinnung von Meerschweinchenmilch. Skand. Arch. Phys., 76, 148, 1937.

115 Goldblith, S. A. and Proctor, B. E. : Effects of high voltage $\mathrm{X}$-rays and cathode rays on vitamins. Nucleonics, 5, 50, 1949.

116 Gordon, H. A. : Comments on surgery and terminal procedures in gnotobiotic experiments. Lab. Anim. Care, 13 (Part 2), 588, 1963.

117 Gordon, H. A. Small scale germfree animal operation. In Technology in Germfree and Gnotobiotic Life Research, edited by Miyakawa \& Wostmann. Academic Press of Japan, Tokyo (1969).

118 Gordon, H. A. and Pesti, L. : The gnotobiotic animal as tool in the study of host microbial relationships. Bact. Rev., 35, 390, 1971.

119 Grace, O. D., Underdahl, N. and Young, G. A. : Procurement of lambs by hysterectomy and their isolation. Am. J. Vet. Res., 20, 239, 1959.

120 Graham, W. R. : Recovery of a pleuropneumonia-like organism (P. P. L. O.) from the genitalia of the female albino rat. Lab. Anim. Care, 13, 719, 1963.

121 Graham, W. R. and Feenstra, E. S.: A program for the development of pathogen-free laboratory animals. Proc. Anim. Care Panel, 8, 54, 1958.

122 Greenspan, F. P.: The convenient preparation of peracids. J. Am. Chem. Soc., 69, 907, 1946.

123 Greenspan, F. P.: Oxidation reactions with aliphatic peracids. Indust. Engrg. Chem., 39, 847, 1947.

124 Greenspan, F. P. and Mackellar, D. G. : The application of peracetic acid germicidal washes to mold control of potatoes. Food Tech., 5, 95, 1951.

125 Griesemer, R. A. : Control of disease with germfree methods. In Swine in Biomedical Research. Trayn Printing, Washington (1966).

126 Griesemer, R. A. and Gibson, J. P. : The gnotobiotic dog. Lab. Anim. Care, 13 (Part 2), 643, 1963.

127 Griesemer, R. A. and Gibson, J. P. : The esta- blishment of an ascarid-free beagle dog colony. J. Am. Vet. Med. Assoc., 143, 965, 1963.

128 Griesemer, R. A., Gibson, J. P. and Elsasser, D. S. : Congenital ascariasis in gnotobiotic dogs. J. Am. Vet. Med. Assoc., 143, 962, 1963.

129 Gustafsson, B. : Germfree rearing of rats. Preliminary report. Acta Anat., 2, 376, 1947.

130 Gustafsson, B. : Germfree rearing of rats. General technique. Acta Path. Microb. Scand., 73 (Suppl.), 1948.

131 Gustafsson, B. : Germfree rearing of laboratory animals. Present technique and problems. Nord. Med., 58, 1515, 1957.

132 Gustafsson, B. : Recent progress in germfree research. Nord. Med., 61, 734, 1959.

133 Gustafsson, B. : Light weight stainless steel systems for rearing germfree animals. Ann. N. Y. Acad. Sci., 78, 17, 1959.

134 Gustafsson, B. : Germfree research at the Institute of Histology, University of Lund. Recent Prog. Microb., 7, 327, 1959.

135 György, P. : Observations on germfree animals at The Walter Reed Army Institute of Research. Recent Prog. Microb., 7, 288, 1959.

136 Haacks, H., Heine, W. and Thunert, A. : Raising specified pathogen-free guinea pigs and rabbits by using gnotobiotechniques. In Germfree Research Biological Effect of Gnotobiotic Environments, edited by Heneghan. Academic Press, N. Y. \& London (1973).

137 Haelterman, E. O. : Practical isolation equipment for baby pigs. Am. J. Vet. Res., 17, 129, 1956.

138 Haenni, E. O., Affens, W. A., Lanto, H. G., Yeomans, A. and Fulton, R. A. : New nonflammable formulations for sterilizing sensitive materials. Indust. Engrg. Chem., 51, 685, 1959.

139 Hall, L. H. : Ethylene oxide process reduces spoilage organisms. Food Packer, 26, 28, 1951.

140 Hambreaeus, A. and Sanderson, A. F. : The control by ventilation of airborne bacterial transfer between hospital patients, and its assessment by means of a particle tracer III Studies with an airborne-particle tracer in an isolation ward for burned patients. J. Hyg. Camb., 70, 299, 1972. 
141 Hannan, R. S. : Preservation of food with ionizing radiation. Nature, 173, 752, 1954.

142 Harrison, G. F. : Production of germf ree chicks: A comparison of the hatchability of eggs sterilized externally by different methods. Lab. Anim., 3, 51, 1969.

143 Harris-Smith, R. and Pirt, S. J. : A ventilated germfree cabinet for the microbiological laboratory. Biotech. Bioengrg, 5, 53, 1963.

144 Hart, R. : A technique for the derivation of lambs by hysterotomy. Brit. Vet. J., 127, 419, 1971.

145 橋本義雄, 榊原欣作, 森澄, 榊原文作, 鷲津卓爾, 高橋英作, 宮川正澄, 宇野裕, 桜井弘 (Hashimoto, Y., Sakakibara, K., Mori, K., Sakakibara, B., Washizu, T., Takahashi, E., Miyakawa, M., Uno, Y. and Sakurai, H.) : 絶対無菌環境下手 術 (Germfree operation). 手術 (Operation), 20, 973, 1966.

146 Hashimoto, Y., Sakakibara, K., Mori, K., Sakakibara, B., Washizu, T. and Takahashi, H. : Germfree surgical operation. In Advances in Germfree Research and Gnotobiology, edited by Miyakawa \& Luckey. Iliffe Book, LondonChemical Rubber, Ohio (1968).

147 Hashimoto, Y., Sakakibara, K., Mori, K., Sakakibara, B., Washizu, T. and Takahashi, H. : Germfree operation. In Technology in Germfree and Gnotobiotic Life Research, edited by Miyakawa \& Wostmann. Academic Press of Japan, Tokyo (1969).

148 Hawks, E. A. and Michelson, O. : Nutritional changes in diets exposed to ethylene oxide. Sci., 121, 442, 1955.

149 Heine, W.: About planning and designing of barrier type animal laboratories for research. Z. Versuchstierk., 8, 335, 1966.

150 Heine, W. : Gnotobiotechnik. Verlag M. \& H. Schaper, Hannover (1968).

151 Heine, W. and Thunert, A. : The establishment of a division of gnotobiology and conceptions of special barrier type animal houses. In Advances in Germfree Research and Gnotobiology, edited by Miyakawa \& Luckey. Iliffe Book, London-Chemical Rubber, Ohio (1968).

152 Heine, W. and Thunert, A.: Unterdruckisolatoren zur Arbeit mit pathogenen Keimen. Z.

Med. Mikrob. Immun., 155, 81, 1969.

153

Dekker, I. P., Slump, R. and Willems, J. J.

Slump, R. and Willems, J. J. L. : Nutritive value of canned meals. Effect of heat sterilization and prolonged storage. J. Am. Diet. Assoc., 58, 434, 1971.

154 Heneghan, J. B. : Problems of germfree animal surgery. In Technology in Germfree and Gnotobiotic Life Research, edited by Miyakawa \& Wostmann. Academic Press of Japan, Tokyo (1969).

155 Heneghan, J. B. (Editor) : Germfree Research Biological Effect of Gnotobiotic Environments. Academic Press, N. Y. \& London (1973).

156 Heneghan, J. B. and Backer, E. P. : Effects of peracetic acid on gnotobiotic animals. Lab. Anim. Care, 14, 323, 1964.

157 Heneghan, J. B. and Cohn, Jr., I. : Growth of germfree dogs fed different diets. Lab. Anim. Care, 13, 545, 1963.

158 Heneghan, J. B., Floyd, C. E. and Chon, Jr., I. : Gnotobiotic dogs for surgical research. J. Surg. Res., 6, 24, 1966.

159 Heneghan, J. B. and Gates, D. F. : Effects of peracetic acid used in gnotobiotics on experimental animals. Lab. Anim. Care, 16, 96, 1966.

160 Heneghan, J. B., Longoria, S. G. and Cohn, Jr., I. : The growth of germfree beagles. Am. Surg., 34, 82, 1968.

161 Heneghan, J. B., Longoria, S. G. and Cohn, Jr., I. : Maintenance and growth of gnotobiotic beagle dogs. In Advances in Germfree Research and Gnotobiology, edited by Miyakawa \& Luckey. Iliffe Book, London-Chemical Rubber, Ohio (1968).

162 Heneghan, J. B., Longoria, S. G. and Cohn, Jr., I. : Reproduction in germfree beagles. Adv. Exp. Med. Biol., 3, 367, 1969.

163 Heneghan, J. B., Longoria, S. G. and Cohn, Jr., I. : Gnotobiotic beagles: Maintenance, growth and reproduction. In Defining the Laboratory Animal, edited by NAS., Nat. Acad. Sci., N. Y. (1971).

164 Henfrey, K. M. : Equipment and labour-saving devices with special consideration of intergrating equipment with design of building and 
services to be proved. In Laboratory Animal Symposia 1 The Design and Function of Laboratory Animal Houses, edited by Hare \& O' Donoghue. Laboratory Animal Ltd., London (1968).

165 Henthrone, R. D. and Kester, W. O. : Diseasefree laboratory animals as related to germfree life. Ann. N. Y. Acad. Sci., 78, 276, 1959.

166 Hickey, J. L. S.: Germfree sanitary engineering. Am. J. Pub. Hlth, 52, 192, 1962.

167 Hill, B. F.: The gnotobiote and the production of laboratory animals. Lab. Anim. Care, 13 (Part 2), 622, 1963.

168 Hill, I. R. and Kenworthy, R. : Determination of the microbiological status of gnotobiotic pigs. J. Appl. Bact., 32, 408, 1969.

169 Hiller, H. H., Thimm, H. J., Eichberg, J. and Juhr, N. C. : Aufzucht von Katzen unter keimfreier Bedingungen. Berl. Münch. Tierärztl. Wschr., 82, 417, 1969.

170 Hills, D. M. and McDonald, I. : Hand rearing of rabbits. Nature, 178, 704, 1956.

171 Hoerlein, A. B., Adams, C. H. and Meade, R. J. : Hysterotomy to obtain "disease-free" baby pigs. J. Am. Vet. Med. Assoc., 128, 127, 1956.

172 Hoffman, R. K. and Warshowsky, B. : Betapropiolactone vapor as a disinfectant. Appl. Microb., 6, 358, 1958.

173 Hollingsworth, R. L., Rowe, V. K., Oyen, F., McCollonster, D. D. and Spencer, H. C. : Toxicity of ethylene oxide determined on experimental animals. A. M. A. Arch. Indust. Hlth, 13, 217, 1956.

174 Hörter, R. : Untersuchungen an pelletierten Futtermitteln und ihre Eignung für SPF-Versuchstiere. Berl. Münch. Tierärztl. Wschr., 17, 339, 1968.

175 Horton, R. E. and Hickey, J. L. S. : Irradiated diets for rearing germfree guinea pigs. Proc. Anim. Care Panel, 11, 93, 1961.

176 細谷祐太郎(Hosogai，Y.).：エポキサイドガス 殺菌剤について(Epoxide gaseous antimicrobial agent). 食衛誌(J. Food Hyg. Soc. Jap.), 12, 349, 1971.

177 Hotzel, D. and Barnes, R. H.: Contributions of the intestinal microflora to the nutrition of the host IV Gnotobiotic rearing and coprophagy. In Vitamines and Hormones Vol. 24, edited by Harris et al. Academic Press, N. Y. \& London (1966).

178 Howarth, G., Fennestad, K. L. and Hjarde, W. : Stability of vitamin $\mathrm{C}$ in a compressed diet for guinea-pigs. Z. Versuchstierk., 14, 205, 1972.

179 Howie, J. H. (Chairman). : Sterilization by steam under increased pressure. Lancet, (1), $425,1959$.

180 Hummel, R. P., Maley, M. and MacMillan, B. G.: Technical advances in patient isolation. Adv. Exp. Med. Biol., 3, 11, 1969.

181 Humphrey, A. E. and Gaden, Jr., E. L.: Air sterilization by fibrous media. Indust. Engrg. Chem., 47, 924, 1955.

182 Hunt, R. D., King, N. W. and Foster, H. L. : Encephalitozoonosis: Evidence for vertical transmission. J. Inf. Dis., 126, 212, 1972.

183 井上宇市 (Inoue, U.) : 病院などにおけるバイオク リーンの技術 (Bioclean technology in the medical facilities). 医器誌(J. Jap. Med. Instruments), 42, 389, 1972.

184 磯村信行 (Isomura, N.) : M-51 型無菌飼育装置の 構造並びに飼育法に関する基礎的研究 (The basic studies on germfree rearing of guinea pigs using the unit Type M-51). 名古屋医学(J. Nagoya Med. Assoc.), 73, 257, 1957.

185 伊藤誠 (Itoh, M.) : 無菌病室の建築設計(Design of laminar flow patient isolation room). 空気清 浄(Jap. Air Cleaning Assoc.), 11(2), 25, 1973.

186 岩藤誠吾, 鈴木善雄, 飯塚広, 紫部禎已, 仲川憲一 (Iwato, S., Suzuki, Y., Iizuka, H., Shibabe, S. and Nakagawa, K.) : 放射線滅菌飼料関する研 究 I 無菌動物用飼料への応用(Sterilization of laboratory animal diets by gamma radiation I Breeding of barrier-sustained animals with irradiated diets). 実験動物 (Exp. Anim.), 19, 77, 1970.

187 岩藤誠吾, 鈴木善雄, 飯堟広 (Iwato, S., Suzuki, Y. and Iizuka, H.) : 放射線滅菌飼料に関する研究 II SPF ラットの繁殖試験挹よび世代試験 (Sterilization of laboratory animal diets by gamma radiation II Reproduction and generation tests on barrier-sustained rats fed with irradiated diets). 実験動物 (Exp. Anim.), 21, 189, 1972. 
188 Jaworski, N. A. and Miller, C. E. : Refinement of the cylinder technique for supplying germfree plastic isolators. Lab. Anim. Care, 13 (Part 2), 591, 1963.

189 Jensen, M. M. : Inactivation of airborne viruses by ultraviolet irradiation. Appl. Microb., 12, 418, 1964.

190 Jordan, H. V., Fitzgerald, R. J. and Poole, W. L.: Studies on heat treatment of a cariogenic diet. J. Dent. Res., 37, 52, 1958.

191 Joshi, N., Blackwood, A. C. and Dale, D. G. : A simple chemical method for the detection of leaks in flexible isolators. Can. J. Comp. Med. Vet. Sci., 28, 126, 1964.

192 Judge, L. F. and Pelczar, Jr., M. J.: The sterilization of carbohydrates with liquid ethylene oxide for microbiological fermentation test. Appl. Microb., 3, 292, 1955.

193 Juhr, N. C. : Eine einfache Vorrichtung für Eingriffe an gnotobiotischen Versuchstieren.

Z. Versuchstierk., 13, 177, 1971.

194 Juhr, N. C.: Die Cäcomegalie keimfreier Nager. Berl. Münch. Tierärztl. Wschr., 85, 4, 1972.

195 Juhr, N. C., Obi, S., Hiller, H. H. and Eichberg, J. : Mycoplasmen bei "keimfreien" Ratten und Mäusen. Z. Versuchstierk., 12, 318, 1970.

196 科学技術庁研究調整局(Research Cordination Bureau, The Science \& Technology Agency): 実験動物に関する総合研究中間研究報告書 (1968) (Research on Experimental Animals: Interim Report, Japan).

197 Kajima, M.: Viral status of germfree rodents; present and future. Adv. Exp. Med. Biol., 3, $117,1969$.

198 Kajima, M. and Pollard, M.: Detection of virus-like particles in germfree mice. J. Bact., 90, 1448, 1965.

199 Kalter, S. S., Eichberg, J. and Heberling, R. L. : Raising germfree baboons(Papio cynoce phalus). In Germfree Research Biological Effect of Gnotobiotic Environments, edited by Heneghan. Academic Press, N. Y. \& London (1973).

200 金内長司, 光岡知足, 山本脩太郎, 瀬賀利夫 (Kaneuchi, C., Mitsuoka, T., Yamamoto, S. and Sega, T.) : ニワトリの無菌飼育に関する研究 I 新しい飼育装置について (Studies on the rearing of germfree chickens I A new germfree chicken cage). 日獣誌(Jap. J. Vet. Sci.), 28, 1, 1966.

201 金内長司, 光岡知足, 山本脩太郎, 瀬賀利夫 ( Kaneuchi, C., Mitsuoka, T., Yamamoto, S. and Sega, T.) : ニワトリの無菌飼育.に関する研究 II 飼育成績について(Studies on the rearing of germfree chickens II Results of rearing in cages). 日獣誌 (Jap. J. Vet. Sci.), 28, 229, 1966.

202 Kaplan, J.: Hand-rearing infant squirrel monkeys. Lab. Primate Newsletter, 9, 5, 1970.

203 Kappel, H. K. : Establishment of a hysterectomy-derived pathogen-free breeding nucleous of BLUE: (LE) rats. Lab. Anim. Care, 19, 138, 1969.

204 柏崎守, 波岡茂郎, 湯本健吾, 柴田重孝, 赤池洋二 (Kashiwazaki, M., Namioka, S., Yumoto, K., Shibata, S. and Akaike, Y.)：無菌豚の飼育に 関する研究 I 飼育装置および 子豚摘出について (Studies on the rearing of germfree pigs I A germfree rearing isolator apparatus and procurement of baby pigs). 実験動物(Bull. Exp. Anim.), 16, 85, 1967.

205 柏崎守, 波岡茂郎, 湯本健吾, 柴田重孝, 赤池洋二 (Kashiwazaki, M., Namioka, S., Yumoto, K., Shibata, S. and Akaike, Y.) : 無菌豚の飼育に 関する研究 II 飼育成績について (Studies on the rearing of germfree pigs II Rearing of germfree pigs in isolators). 実験動物(Bull. Exp. Anim.), 16, 93, 1967.

206 河井正太郎, 斉藤佐文(Kawai, M. and Saito, S.) : ニワトリの無菌飼育に関する研究 (Studies on germfree rearing of chicks). 千葉医会誌 ( $\mathrm{J}$. Chiba Med. Soc.), 30, 750, 1954.

207 川出盛也(Kawade, S.) : 無菌手術室のバイオク リーン技術(Bioclean techniques for germfree operation room). 空気清浄 (Jap. Air Cleaning Assoc.), 11(2), 33, 1973.

208 Kaye, S.: The sterilization action of gaseous ethylene oxide III The effect of ethylene oxide and related compounds upon bacterial aerosols. Am. J. Hyg., 50, 289, 1949.

209 Kaye, S.: The use of ethylene oxide for the sterilization of hospital equipment. J. Lab. Clin. Med., 35, 823, 1950.

210 Kaye, S. and Philips, C. R.: The sterilizing 
action of gaseous ethylene oxide IV The effect of moisture. Am. J. Hyg., 50, 296, 1949.

211 Kellogg, T. E. and Wostmann, B. S. : Stock diet for colony production of germfree rats and mice. Lab. Anim. Care, 19, 812, 1969.

212 Kelsey, J. C.: Strilization by ethylene oxide. J. Clin. Path., 14, 59, 1961.

213 Kelsey, J. C.: The testing of sterilizers 2 Thermophilic spore papers. J. Clin. Path., 14, 313, 1961.

214 Kelsey, J. C., Beely, M. M. and Whitehouse, C. W. : A capacity use-dilution test for disinfectants. Mon. Bull. Minist. Hlth Lab. Serv., 24, 152, 1965.

215 Kelsey, J. C. and Sykes, G. : A new test for the assessment of disinfectants with particular reference to their use in hospitals. Pharm. J., 202, 607, 1969.

216 Kempe, L. L. : Combined effects of heat and radiation in food sterilization. Appl. Microb., 3, 346, 1955.

217 Kennedy, T. S. and Ley, F. J. : Studies on the combined effect of gamma radiation and cooking on the nutritional value of fish. J. Sci. Food Agric., 22, 146, 1971.

218 Klarenbeek, A. and van Tongeren, H. A. : Virucidal action of ethylene oxide gas. J. Hyg. Camb., 52, 525, 1954.

219 Knappen, F., Schulz, K. D., Wilk, W. and Korn, O.: Methoden und Ergebnisse zur Eignungsprüfung von Futterarten für die Haltung und Zucht von SPF-Ratten 1 Einfluß der Hochdruckdampfsterilisation auf die Struktur von pelletiertem Rattenfutter. Arzneim. Forsch., 21, 2046, 1971.

220 Knox, R. and Penikett, E. J. : Influence of initial vacuum on steam sterilization of dressings. Brit. Med. J., (1), 680, 1958.

221 小林寛伊 (Kobayashi, K) : 手術部における消毒 と滅菌 (Disinfection and sterilization for operation area). 医器誌 (J. Jap. Med. Instruments), 43, 530, 1973.

Kotake, Y., Sotokawa, Y. and Miyakawa, M. : The changes of amino acid-contents in diet protein for germfree animals during sterilization. In Technology in Germfree and Gnotobiotic Life Research, edited by Miyakawa \&
Wostmann. Academic Press of Japan, Tokyo (1969).

223 Kraybill, H. F. : Nutritive effects of food sterilized by ionizing radiation. Nutr. Rev., 13, 193, 1955.

224 Kraybill, H. F. : Radiation preservation of food. Pub. Hlth Rep., 72, 675, 1957.

225 Kung, H. C., Garden, E. L. and King, C. G. : Vitamins and enzymes in milk. Effect of gamma radiation on activity. Agric. Food Chem., 1, 142, 1953.

226 倉益茂美 (Kuramasu, S.) : ブタ. 田嶋編 実験 動 物学各論, 朝倉書店, 東京 (1972) (The pigs. In Handbook of Laboratory Animal Science II, edited Tajima. Asakura-Shoten, Tokyo).

227 Küster, E. : Die keimfreier Züchtung von Säugetieren-und ihre Bedeutung für die Erforschung der Körperfunktionen. Zbl. Bakt. I. Ref., 54, 55, 1912.

228 Küster, E. : Die Gewinnung und Züchtung keimfreier Säugetiere. Deut. Med. Wschr., 39, 1986, 1913.

229 LoGrippo, G. A., Overhulse, P. R., Szilagyi, D. E. and Hartman, F. W.: Procedure for sterilization of arterial homografts with beta-propiolactone. Lab. Invest., 4, 217, 1955.

230 Landy, J. J. : Sterile operative technique. J. Arkansas Med. Soc., 57, 503, 1961.

231 Landy, J. J. and Ledbetter, R. K. : Delivery and maintenance of the germfree pig. In Swine in Biomedical Research. Trayn Printing, Washington (1966).

232 Landy, J. J., Yerasimides, T. G., Growdon, J. H. and Bausor, S. C. : Germfree guinea pig delivery by hysterectomy. Surg. Forum, 11, 425, 1960.

233 Lane-Petter, W.: A ventilation barrier to the spread of infection in laboratory animal colonies. Lab. Anim., 4, 125, 1970.

234 Legrace, A. : La production de porc SPF. Inform. Vet., 4, 17, 1962.

235 Lev. M.: Germfree animals and their uses in elucidating the action of the gut flora on the host. J. Appl. Bact., 24, 307, 1961.

236 Lev, M. : Germfree animals in laboratory uses. In Antibiotics in Agriculture, edited by Woodbine. Butterworths, London (1962). 
237 Lev. M. : An autoclavable plastic unit for rearing animal under germfree conditions. J. Appl. Bact., 25, 30, 1962.

238 Lev, M. : Germfree animals. In Animals for Research, edited by Lane-Petter. Academic Press, N. Y. \& London (1963).

239 Lev, M. : A divice for the external supply of sterile water and a simple air sterilizing filter for germfree units. J. Appl. Bact., 27, 41, 1964.

240 Levenson, S. M., Mason, R. P., Huber, T. E., Malm, O. J., Horowitz, R. E. and Einheber, A. : Germfree animals in surgical research. Ann. Surg., 150, 713, 1959.

241 Levenson, S. M., Trexler, P. C. and LaConte, M. : Application of the technology of the germfree laboratory to the special problems of patient care. Am. J. Surg., 107, 710, 1964.

242 Levenson, S. M., Trexler, P. C., Malm, O. J., Horowitz, R. E. and Moncrief, W. H.: Disposable plastic isolator for operating in sterile environment. Surg. Forum., 11, 306, 1960.

243 Levenson, S. M., Trexler, P. C., Malm, O. J., LaConte, M. L., Horowitz, R. E. and Moncrief, W. H.: A plastic isolator for operating in a sterile environment. Am. J. Surg., 104, 891, 1962.

244 Levin, L.: A simple method for rapid tube feeding of rats. Sci., 96, 477, 1942.

245 Ley, F. J. : The use of irradiation for the treatment of various animal feed products. Food Irradiation Information, No. 4 (1972) (佐藤友太郎訳 : 飼料の放射線処理による滅菌, 畜 産の研究, 27, 1237, 1973).

246 Ley, F. J., Bleby, J., Coates, M. E. and Paterson, J. S. : Sterilization of laboratory animal diets using gamma radiation. Lab. Anim., 3, 221, 1969 .

247 Ley, F. J., Winsley, B., Barbord, P., Keall, A. and Summers, T. : Radiation sterilization: $\mathrm{Mi}$ crobiological findings from subprocess dose treatment of disposable plastic syringes. J. Appl. Bact., 35, 53, 1972.

248 Lidwell, O. M. : The control by ventilation of airborne bacterial transfer between hospital patients, and its assessment by means of a particle tracer II Ventilation in subdivided iso- lation units. J. Hyg., Camb., 70, 287, 1972.

249 Linsley, J. G. and Yale, C. E. : A lightweight stainless steel isolation system for adult gnotobiotic dogs. In Germfree Research Biological Effect of Gnotobiotic Environments, edited by Heneghan. Academic Press, N. Y. \& London (1973).

250 Lopushinsky, T. : Axenic cottontails. Gnot. Newsletter, 4, 2, 1968.

251 Lougnon, J. and Rérat, A. : Traitement thermique et qualité des proteines du soja IV Effet de la cuisson des tourteaux et de leur supplémentation par des amino-acides sur la croissance et la pétention azotée chez le rat. Ann. Zootech., 20, 41, 1971.

252 Lowbury, E. J. L. : Skin disinfection. J. Clin. Path., 14, 85, 1961.

253 Luckey, T. D. : Nutrition and biochemistry of germfree chicks. Ann. N. Y. Acad. Sci., 78, 127, 1959.

254 Luckey, T. D. : Germfree Life and Gnotobiology. Academic Press, N. Y. \& London (1963).

255 Luckey, T. D. : Gnotobiology and aerospace systems. In Advances in Germfree Research and Gnotobiology, edited by Miyakawa \& Luckey. Iliffe Book, London-Chemical Rubber, Ohio (1968).

256 Luckey, T. D.: Gnotobiotic rooms. In Technology in Germfree and Gnotobiotic Life Research, edited by Miyakawa \& Wostmann. Academic Press of Japan, Tokyo (1969).

257 Luckey, T. D., Mende, T. J. and Pleasants, J. : The physical and chemical characterization of rat's milk. J. Nutr., 54, 345, 1954.

258 Luckey, T. D., Wagner, M., Gordon, H. A. and Reyniers, J. A. : Rearing germfree turkeys. Lobund Rep., 3, 176, 1960.

259 Luckey, T. D., Wagner, M., Reyniers, J. A. and Foster, Jr., F. L. : Nutritional adequacy of a semi-synthetic diet sterilized by cathode rays. Food Res., 20, 170, 1955.

260 Lutsky, I. and Organick, A. : Pneumonia due to mycoplasma in gnotobiotic mice. J. Bact., 92, 1154, 1966.

261 Lutsky, I. and Organick, A.: Recovery of mycoplasma from gnotobiotic systems. Lab. Anim. Care, 18, 610, 1968. 
262 Mackenzie, M. R., Dooren, L. J. and Ruys, J. H. : The first germfree born child; hereditary agammaglobulinanemia. Nord. T. Geneesk., 113, 1755, 1969.

263 前島一淑 (Maejima, K.) : 無菌動物の微生物学的 統御に関する諸問題——とくにアイソレータの構 造と滅菌方法について-_(Some problems on the microbiological control for germfree rearing). 実験動物 (Exp. Anim.), 22, 223, 1973.

264 前島一淑, 木内吉寛, 浦野徹, 伊藤喜久治, 竹中 参二, 藤原公策 (Maejima, K., Kiuchi, Y., Urano, T., Itoh, K., Takenaka, S. and Fujiwara, K.) : 無菌マウスの飼育と実験に要する作業時間 (Time required for rearing and experiment of germfree mice). 実験動物 (Exp. Anim.), 21, 19, 1972.

265 前島一淑，水尾昭江，柴田俊夫 (Maejima， K., Mizuo, A. and Shibata, T.): 過酢酸の定量法と 安定性 (A method for examination of the oxidizing power and stability of peracetic acid). 実験動物 (Exp. Anim.), 22, 263, 1973.

266 前島一淑, 森田茂男, 田嶋嘉雄, 柴田俊夫 (Maejima, K., Morita, S., Tajima, Y. and Shibata, T.) : アイソレータの組立と操作，東京 (1969) (Handbook for Germfree Isolators).

267 前島一淑, 鈴木潔，小林理造, 須藤カッ子, 伊藤喜 久治 (Maejima, K., Suzuki, K., Kobayashi, R., Sudo, K. and (toh, K.): 東京大学医科学研究所動 物センター繁殖室に設置されたオートクレーブの 滅菌条件に関する検討(Sterilization conditions of the autoclave equipped in the Breeding Section of Laboratory Animal Center, Institute of Medical Science, University of Tokyo). 実験動物 (Exp. Anim.), 22, 31, 1973.

268 Markowitz, J., Archibald, J. and Downie, H. G. : The germfree animals (Gnotobiotes). In Experimental Surgery, edited by Markowitz. Williams \& Wilkins, Baltimore (1964). mura, H.) : マウスの無菌飼育一必要最小限の装 置による一免疫学会編 免疫実験 操作法, 1972 年 増補 (A minimum requirement for apparatus of germfree rearing mice).

270 McCulloch, E. R.: Disinfection and Sterilization, 2nd ed. Lea \& Febiger, Philadelphia (1945).

271 McDaniel, E. G. and Daft, F. S. : Techniques in care and feeding of germfree animals. Proc. Anim. Care Panel, 11, 107, 1961.

272 Mebus, C. A., Underdahl, N. R. and Twiehaus, M. J.: Isolation unit used in studies on neonatal calf diarrhea. Am. J. Vet. Res., 33, 2335, 1972.

273 Meier, H. : Spontaneous cytomeglic inclusion body disease involving lacrimal glands of caesarian-derived (so-called) pathogen-free rats. Nature, 188, 506, 1960.

274 Merkenschlager, M., Juhr, N. C., Hiller, H. H. and Eichberg, J.: Aufzucht von Hunden unter keimfreier Bedingungen. Z. Versuchstierk., 11, 285, 1969.

275 Meyer, R. C., Bohl, E. H., Henthorne, R. D., Tharp, V. L. and Baldwin, D. E.: The procurement and rearing of gnotobiotic swine: Procedures currently in use for the procurement and rearing of germfree and gnotobiotic swine at the Ohio State University. Lab. Anim. Care, 13(Part 2), 655, 1963.

276 Meyer, R. C., Bohl, E. H. and Kohler, E. : Procurement and maintenance of germfree swine for microbiological investigations. Appl. Microb., 12, 295, 1964.

277 Mickelsen, O. : Nutrition-Germfree animal research. Ann. Rev. Biochem., 31, 515, 1962.

278 Miller, H. T. and Luckey, T. D. : A new germfree chicken cage-Characteristics and use. Appl. Microb., 10, 52, 1962.

279 Miller, O. T., Schmitt, R. F. and Phillips, G. B.: Applications of germicidal ultraviolet in infectious disease laboratories I Sterilization of small volumes of air by ultraviolet irradiation. Am. J. Publ. Hlth, 45, 14201955.

280 Mirand, E. A. and Back, N. (Editors) : Germfree Biology Experimental and Clinical Aspects (Adv. Exp. Med. Biol., Vol. 3), Plenum Press, N. Y. (1969).

281 宮川正澄 (Miyakawa, M.) : 実験動物の無菌飼育 について(Rearing germfree experimental animals). 日新医学 (Nisshin Igaku), 42, 553, 1955. Miyakawa, M. : Report on germfree research at the Department of Pathology, University of Nagoya, Japan, and some observations on wound healing, transplantation and foreign body inflammation in the germfree guinea 
pigs. Recent Prog. Microb., 7, 299, 1959. germfree rearing unit. Ann. N. Y. Acad. Sci., 78, 37, 1959.

284 宮川正澄 (Miyakawa，M) : 無菌動物. 医歯薬出 版, 東京 (1963) (Germfree Animals. IshiyakuShuppan, Tokyo).

285 Miyakawa, M.: Studies on rearing germfree rats. In Advances in Germfree Research and Gnotobiology, edited by Miyakawa \& Luckey. Iliffe Book, London-Chemical Rubber, Ohio (1968).

286 宮川正澄 (Miyakawa, M.) : 無菌動物一一医学生 物学への応用. 医歯薬出版, 東京 (1973) (Germfree Animals-Their Application to Medicine and Biology. Ishiyaku-Shuppan, Tokyo).

287 Miyakawa, M. and Luckey, T. D. (Editors): Advances in Germfree Research and Gnotobiology. Iliffe Book, London-Chemical Rubber, Ohio (1968).

288 Miyakawa, M., Sakurai, K., Sumi, Y. and Uno, Y.: Germfree isolators and physiology of germfree rats: A comparison between M-51 and MS-65 type isolators. In Technology in Germfree and Gnotobiotic Life Research, edited by Miyakawa \& Wostmann. Academic Press of Japan, Tokyo (1969).

289 Miyakawa, M., Sumi, Y., Hirano, T., Sakurai, K., Kojima, K., Umeki, T. and Uno, Y. (宮川正澄, 䐴見幸子, 平野拓男, 桜井弘一，小島 汃え, 梅木達枝, 宇野裕) : Studies on germfree rearing of pigs (ブタの無菌飼育). Jap. J. Vet. Sci. (日獣誌), 31，199，1969.

290 Miyakawa, M. and Wostmann, B. S. (Editors): Technology in Germfree and Gnotobiotic Life Research. Academic Press of Japan, Tokyo (1969).

291 Moore, T. D., Allen, A. M. and Ganaway, J. R. : Latent Pasteurella pneumotropica infection of the gnotobiotic and barrier-held rats. Lab. Anim. Sci., 23, 657, 1973.

292 Morita, M., Tajima, M. and Fujimaki, M. : Preferential loss of conjugated carbonyl compounds in cooked pork fat by $\gamma$-irradiation. Agric. Biol. Chem., 35, 1936, 1971.

293 Morris, H. P. and Thompson, J. W. : Convenient inexpensive device for quantitative hand feeding of mice. J. Nat. Cancer Inst., 1, 395, 1940.

294 無菌試験の 規準に関する委員会 (Committee for Standardization of Sterility Test for Germfree Animals in Japan) : 無菌動物の無菌試験法につ いて (Recommended requirement for sterility test of germfree animals, provisional). 実験動 物 (Exp. Anim.), 21, 35, 1972.

295 村田行夫, 勝俣是五郎, 多田檀, 鈴木祥太, 油井 享 (Murata, Y., Katsumata, Y., Tada, M., Suzuki, S. and Yui, T.) : SPF ウサギ繁殖 Colony の 確立(第 1 報) 作出育成法とその維持 (Experimental trials on the establishment of breeding colony of the specific-pathogen-free rabbit I Procedures for establishment and maintenance). 武田研究所報 (J. Takeda Res. Lab.)， 31，42, 1972.

296 長井淳, 村山良介 (Nagai，J. and Murayama, Y.) : Wrightington 病院および京大病院における 無菌手術室について (Charnley's clean-air operating enclosure and laminar operating room in Kyoto Univ. Hospital). 空気清浄 (Jap. Air Cleaning Assoc.), 11 (2), 18, 1973.

297 Nagata, I. : Microbiological studies on germfree animals. In Technology in Germfree and Gnotobiotic Life Research, edited by Miyakawa \& Wostmann. Academic Press of Japan, Tokyo (1969).

298 中原毅 (Nakahara, T.) : 哺乳動物 無菌飼育 装置. の研究 (Studies on the apparatus for germfree rearing of mammals). 千葉医会誌(J. Chiba Med. Soc.), 35, 791, 1959.

299 波岡茂郎 (Namioka, S.) : SPF 豚とその作出 (SPF swine). 畜産の研究 (Anim. Husbandry), 19, 1301, 1965.

300 波岡茂郎(Namioka, S.) : SPF 豚(Specific-pathogen-free swine). 日獣師会誌(J. Jap. Vet. Med. Assoc.), 21, 300, 1968.

301 波岡茂郎 (Namioka, S.) : 無菌動物あれてれ (Germfree animals). メディアサークル (Media Circle), No. 98, 25, 1968.

302 波岡茂郎 (Namioka, S.) : SPF 豚の作出とその 飼養環境 1 (Establishment of SPF swine and their rearing environment I). 畜産の研究 (Anim. Husbandry), 26, 74, 1972.

303 波岡茂郎，湯本健吾，柴田重孝 (Namioka， S., Yumoto, K. and Shibata, S.): SPF (specific 
pathogen free) 豚の微生物検定について (Microbiological evaluation of an isolation facility for the production of specific pathogen free pigs). 日獣誌(Jap. J. Vet. Sci.), 29, 21, 1967.

304 Nance, F. C., Lowis, V. and Bornside, G. H. : Absolute barrier isolation and antibiotics in the treatment of experimental burn wound sepsis. J. Surg. Res., 10, 33, 1970.

305 Nelson, J. B. and Collins, G. R. : The establishment and maintenance of a specific pathogen-free colony of Swiss mice. Proc. Anim. Care Panel, 11, 65, 1961.

306 Newton, W. L. : Methods in germfree animal research. In Methods of Animal Experimentation Vol. 1, edited by Gay. Academic Press, N. Y. \& London (1965).

307 新津靖, 吉川暲, 浜名隆 (Niitsu, Y., Yoshikawa, A. and Hamana, T.) : サブミクロンじんあいの ろ過に関する研究 第 3 報 ウレタン・フォーム・フィ ルタのろ過性能 (Researches on filtration of sub-

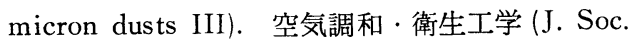
Heating Air-cond. Sanit. Engrg. Jap.), 41, 829, 1967.

308 新津靖, 吉川暲, 久保多貞夫 (Niitsu, Y., Yoshikawa, A. and Kubota, S.) : サブミクロンじん あいのろ過に関する研究 第 4 報 万過効率の理論的 解析 (Researches on filtration of sub-micror. dusts IV). 空気調和, 衛生工学 (J. Soc. Heating Air-cond. Sanit. Engrg. Jap.), 43, 797, 1969.

309 新津靖, 吉川逶, 久保多貞夫 (Niitsu, Y., Yoshikawa, A. and Kubota, S.): サブミクロンじんあ いのろ過関する研究 第 5 報 万過効率に及ぼす フィルタ厚さの影響 (Researches on filtration of sub-micron dusts V). 空気調和, 衛生工学 (J. Soc. Heating Air-cond. Sanit. Engrg. Jap.), 46, 845, 1972.

310 新津靖, 吉川暲, 酒井寛二(Niitsu, Y., Yoshikawa, A. and Sakai, K.) : サブミクロンじんあい のろ過に関する研究 第2 報 ガラス絨維充てん層の 万過性能 (Researches on filtration of sub-micron dusts II). 空気調和. 衛生工学(J. Soc. Heating Air-cond. Sanit. Engrg. Jap.), 40, 613, 1966.

311 Northcote, D. H. and Leader, V. R. : A simple apparatus for the forced feeding of small animals. J. Anim. Tech. Assoc., 4, 40, 1953.
312 Nuttal, G. H. F. and Thierfelder, H. : Thierisches Leben ohne Bakterien im Verdauungskanal. Z. Phys. Chem., 21, 109, 1895.

313 Nuttal, G. H. F. and Thierfelder, H.: Thierisches Leben ohne Bakterien im Verdauungskanal (II Mittheilung). Z. Phys. Chem., 22, 62, 1896.

314 Oace, S. M. : A purified soy protein diet for nutrition studies with germfree rats. Lab. Anim. Sci., 22, 528, 1972.

315 O'Meara, J. P. : Radiation chemistry and sterilization of biological materials by ionizing radiation. Nucleonics, 10, 19, 1952.

316 Orland, F. J., Blayney, J. R., Harrison, R., Reyniers, J. A., Trexler, P. C., Wagner, M., Gordon, H. A. and Luckey, T. D. : Use of germfree animal technique in the study of experimental dental caries I Basic observations on rats reared free of all microorganisms. J. Dent. Res., 33, 147, 1954.

317 Oxender, W. D., Purser, D. B. and Bergen, W. G. : A procedure to obtain germfree goats by hysterotomy. Am. J. Vet. Res., 32, 1443, 1971.

318 Paterson, J. S. and Cook, R. : Utilization of diets sterilized by gamma irradiation for germfree and specific-pathogen-free laboratory animal. In Defining the Laboratory Animal, edited by NAS. Nat. Acad. Sci., N. Y. (1971).

319 Paterson, R. C., Jones, R. W., Cook, R. and Garriock, D. : A simplified fibreglass germfree isolator with facilities for performing dental surgery on rats. Lab. Anim., 4, 233, 1970.

320 Paterson, R. C. and Rowe, A. H. : Surgical anaesthesia in conventional and gnotobiotic rats. Lab. Anim., 6, 147, 1972.

321 Patrick, E. A. K., Wharton, R. H., Prentis, K. and Signy, G.: Sterilization by gas ovens. J. Clin. Path., 14, 62, 1961.

322 Paul, P., Larsen, C. T., Kumar, M. C. and Pomeroy, B. S.: Preliminary observations on egg transmission of turkey herpesvirus (HVT) in turkeys. Avian Dis., 16, 27, 1972.

323 Penikett, E. J. K., Rowe, T. W. G. and Robson, E.: Vacuum drying of steam sterilized dressings. J. Appl. Bact., 21, 82, 1956.

324 Perkins, F. T. and Short, D. J. : A new technique in the sterilization of animal houses, 
racking and cages. J. Anim. Tech. Assoc., 8, 10, 1957. rch. Battelle Technical Review (1963). animals-their application in biological resea-

Sterilization in Health Science, 2nd ed. C. C. Thomas, Illinois (1969).

ins, A. W., Newcomb, H. R. and Bach, F. C. : Experimental preservation of poultry by chlortetracycline and ionizing radiation. Food Tech., 14, 521, 1960.

328 Phillips, A. W., Newcomb, H. R., LaChapelle, R. and Balish, E. : Rearing of germfree and monocontaminated chicks in rigid plastic isolators. Appl. Microb., 10, 224, 1962.

329 Phillips, A. W., Newcomb, H. R., Robinson, T., Bach, F. C., Clark, W. L. and Whitehill, A. W. : Experimental preservation of fresh beef with antibiotics and ionizing radiation. Food Tech., 15, 13, 1961.

330 Phillips, A. W., Newcomb, H. R. and Shanklin, D. R.: Long-term rat feeding studies on irradiated chicken stew and irradiated cabbage. Toxic. Appl. Pharm., 5, 273, 1963.

331 Phillips, A. W. and Smith, J. E. : Germfree animal techniques and their applications. Adv. Appl. Microb., 1, 141, 1959.

332 Phillips, B. P. : Parasitological survay of Lobund germfree animals. Lobund Rep., 3, 172, 1960.

333 Phillips, B. P.: Pneumonic disease in germfree animals. J. Inf. Dis., 108, 12, 1961.

334 Phillips, B. P., Wolfe, P. A. and Gordon, H. A. : Studies on rearing the guinea pig germfree. Ann. N. Y. Acad. Sci., 78, 183, 1959.

335 Phillips, C. R.: The sterilizing action of gaseous ethylene oxide II Sterilization of contaminated objects with ethylene oxide and related compounds: time, concentration and temperature relationships. Am. J. Hyg., 50, 280, 1949.

336 Phillips, C. R. and Hoffman, R. K. : Sterilization of interplanetary vehicles. Sci., 132, 991, 1960.

337 Phillips, C. R. and Kaye, S.: The sterilizing action of gaseous ethylene oxide. Am. J. Hyg., 50, 270, 1949 .
338 Phillips, G. B., Novak, F. E. and Alg, R. L. : Portable inexpensive plastic safety hood for bacteriologists. Appl. Microb., 3, 216, 1955.

339 Phillips, G. B., Reitman, M., Mullican, C. L. and Gardner, Jr., G. C. : Applications of germicidal ultraviolet in infectious disease laboratories III The use of ultraviolet barriers on animal cage racks. Proc. Anim. Care Panel, 7, 235, 1957.

340 Pilgrim, H. I., Parks, R. C. and Law, L. W. : Leukemia in germfree AKR mice. Adv. Exp. Med. Biol., 3, 125, 1969.

341 Pilgrim, H. I. and Thompson, D. B.: An inexpensive autoclavable germfree mouse isolator. Lab. Anim. Care, 13 (Part 2), 602, 1963.

342 Pleasants, J. R.: Rearing germfree cesareanborn rats, mice and rabbits through weaning. Ann. A. Y. Acad. Sci., 78, 116, 1959.

343 Pleasants, J. R. : Animal production and rearing I Small laboratory mammals. In Germfree Animal in Research, edited by Coates. Academic Press, N. Y. \& London (1968).

344 Pleasants, J. R. Reddy, B. S. and Wostmann, B. S. : Chemically defined, water soluble diets adequate for growth and reproduction of germfree mice. Lab. Anim. Care, 14, 324, 1964.

345 Pleasants, J. R., Reddy, B. S. and Wostmann, B. S. : Rearing of germfree rats and mice on chemically defined liquid diets. In Advances in Germfree Research and Gnotobiology, edited by Miyakawa \& Luckey. Iliffe Book, LondonChemical Rubber, Ohio (1968).

346 Pleasants, J. R., Reddy, B. S. and Wostmann, B. S.: Sudden death in germfree mice reared through successive generations on chemically defined liquid diet. Adv. Exp. Med. Biol., 3, 307, 1969.

347 Pleasants, J. R., Reddy, B. S. and Wostmann, B. S.: Qualitative adequancy of a chemically defined liquid diet for reproducing germfree mice. J. Nutr., 100, 498, 1970.

348 Pleasants, J. R., Reddy, B. S., Zimmerman, D. R., Bruckner-Kardoss, E. and Wostmann, B. S. : Growth, reproduction and morphology of naturally born, normally suckled germfree guinea pig. Z. Versuchstierk, 9, 195, 1967. 
349 Pleasants, J. R. and Wostmann, B. S. : Rearing germfree rats on chemically defined antigen low diets. Proc. Ind. Acad. Sci., 72, 87, 1962.

Pleasants, J. R., Wostmann, B. S. and Zimmerman, D. R.: Improved hand rearing methods for small rodents. Lab. Anim. Care, 14, 37, 1964.

351 Pleasants, J. R., Yoshida, T., Wostmann, B. S. and Reddy, B. S.: Experience with colony rearing of germfree guinea pigs and rabbits. In Technology in Germfree and Gnotobiotic Life Research, edited by Miyakawa \& Wostmann. Academic Press of Japan, Tokyo (1969).

352 Pleasants, J. R., Zimmerman, D. R. and Wostmann, B. S. : Hand feeding of suckling rodents. Lab. Anim. Care, 13 (Part 2), 582, 1963.

353 Plonait, H., Bähr, K. H. and Hazem, A. S. : Ein transportfähiger Isolator zur gnotobiotischen Haltung mittelgroßer Versuchstiere. Z. Versuchstierk., 14, 246, 1972.

354 Poiley, S. M.: Observations on the reproductive performance and laboratory use of inbred mice whose ancestors were derived via surgical/isolator techniques. In Germfree Research Biological Effect of Gnotobiotic Environments, edited by Heneghan. Academic Press, N. Y. \& London (1973).

355 Pollard, M.: The search for microbial contaminations in gnotobiotic rats and mice. Proc. Int. Cong. Zool., 16, 145, 1963.

356 Pollard, M.: Germfree animals and biological research. Sci., 145, 247, 1964.

357 Pollard, M.: Viral status of "germfree" mice. Nat. Cancer Inst. Monograph, No. 20, 167, 1965.

358 Pollard, M.: Application of germfree animals to problems in comparative medicine. Adv. Vet. Sci., 11, 139, 1967.

359 Pollard, M.: Germfree animals in cancer research. In Gann Monograph 5: Experimental Animals in Cancer Research, edited by Mühlbock \& Nomura. Maruzen, Tokyo (1968).

360 Pollard, M. and Matsuzawa, T.: Induction of leukemia in germfree mice by X-rays. Am. J. Path., 44, 17, 1964.

361 Pollard, M. and Matsuzawa, T. : Radiation in- duced leukemia in germfree mice. Proc. Soc. Exp. Biol. Med., 16, 967, 1964.

Pollard, M., Teah, B. A. and Kajima, M. : Spontaneous leukemia in germfree AKR mice. Proc. Soc. Exp. Biol. Med., 120, 72, 1965.

363 Porter, G. and Bleby, J. : Ethylene oxide sterilization (Observations on the use of food, cages and nesting materials so sterilised in the breeding mice). J. Inst. Anim. Tech., 17, 160, 1966.

364 Porter, G. and Festing, M. : A comparison between irradiated and autoclaved diets for breeding mice, with observations on palatablity. Lab. Anim., 4, 203, 1970.

365 Porter, G. and Lane-Petter, W.: Observations on autoclaved, fumigated and irradiated diets for breeding mice. Brit. J. Nutr., 19, 295, 1965.

366 Power, F. E.: Evaluation of gaseous ethylene oxide as a sterilant (Adv. Products Corp.).

367 Reddy, B. S., Wostmann, B. S. and Pleasants, J. R. : Nutritionally adequate diets for germfree animals. In The Germfree Animal in Research, edited by Coates. Academic Press. N. Y. \& London (1968).

368 Reddy, B. S., Wostmann, B. S. and Pleasants, J. R. : Protein metabolism in germfree rats fed chemically defined, water-soluble diet and semisynthetic diet. Adv. Exp. Med. Biol,, 3, 301, 1969.

369 Reid, Jr., I. C. and Gates, Jr., A. S. : A method of sterilizing supplies for germfree isolators in plastic bags. Lab. Anim. Care, 16, 246, 1966.

370 Reyniers, J. A. (Editor) : Micrurgical and Germfree Techniques: Their Application to Experimental Biology and Medicine. C. C. Thomas, Illinois (1943).

371 Reyniers, J. A.: Testing of germfree animals for contamination. J. Bact., 52, 399, 1946.

372 Reyniers, J. A. : The control of contamination in colonies of laboratory animals by the use of germfree techniques. Proc. Anim. Care Panel, 7, 9, 1957.

373 Reyniers, J. A.: Design and operation of apparatus for rearing germfree animals. Ann. N. Y. Acad. Sci., 78, 47, 1959. 
374 Reyniers, J. A. and Sacksteder, M. R.: The use of germfree animals and techniques in search for unknown etiologic agents. Ann. N. Y. Acad. Sci., 73, 344, 1958.

375 Reyniers, J. A. and Sacksteder, M. R. : Apparatus and method for shipping germfree and disease-free animals via public transportation. Appl. Microb., 6, 146, 1958.

376 Reyniers, J. A. and Sacksteder, M. R. : Simplified techniques for production, study and use of germfree animals. Proc. Anim. Care Panel, 9, 97, 1959.

377 Reyniers, J. A. and Sacksteder, M. R. : Raising Japanese quail under germfree and conventional conditions and their use in cancer research. J. Nat. Cancer Inst., 24, 1405, 1960.

378 Reyniers, J. A., Sacksteder, M. R. and Ashburn, L. L. : Multiple tumors in female germfree inbred mice exposed to bedding treated with ethylene oxide. J. Nat. Cancer Inst., 32, 1045, 1964.

379 Reyniers, J. A., Trexler, P. C. and Ervin, R. F. : Rearing germfree albino rats. Lobund Rep., 1, 1, 1946.

380 Reyniers, J. A., Trexler, P. C., Ervin, R. F., Wagner, M., Luckey, T. D. and Gordon, H. T. : Rearing germfree chickens. Lobund Rep., 2, 1, 1949.

381 Reyniers, J. A., Trexler, P. C., Ervin, R. F., Wagner, M., Luckey, T. D. and Gordon, H. A.: Some observations on germfree Bantam chickens. Lobund Rep., 2, 117, 1949.

382 Reyniers, J. A., Trexler, P. C., Ervin, R. F., Wagner, M., Luckey, T. D. and Gordon, H. A. : A complete life cycle in the germfree chick. Nature, 163, 67, 1949.

383 Richey, D. J. and Schmittle, S. C. : Inoculating gnotobiotic animals from outside the isolator. Am. J. Vet. Res., 29, 1117, 1968.

384 Richard, J. L., Cysewski, S. J. and Pler, A. C. : Mycoflora of bovine lung, placenta and fetal stomach content. Am. J. Vet. Res., 31, 995, 1970.

385 Robie, D. M. and Walburg, Jr., H. E. : Ethylene-oxide sterilization of plastic-film isolators : A six-year study of operational efficiency. Adv. Exp. Med. Biol., 3, 357, 1969. L. G.: The germfree cat. Lab. Anim. Care, 16, 52, 1966.

387 Rubbo, S. D. and Gardner, J. F.: A Review of Sterilization and Disinfection. Lloyd-Luke, London (1965).

388 Sacquet, E.: Equipment design and management I General technique of maintaining germfree animals. In Germfree Animal in Research, edited by Coates. Academic Press, N. Y. \& London (1968).

389 斉藤宗雄 (Saito, M.) : ビニールアイソレータと その使用法 (Vinyl isolator). クレアニュース (CLEA News), No. 8, 1, 1969.

390 Salle, A. J. and Korzenovsky, M. : Effect of a vacuum on destruction of bacteria by germicides. Proc. Soc. Exp. Biol. Med., 50, 12, 1942.

391 桜井弘一 (Sakurai, K.) : 両性界面活性剂の消毒効 果およびその毒性についての病理組織学的 研究一 一無菌飼育実験への応用 (Histopathological studies on the antiseptic powers and toxicity of the amphoretic surface active agent di (octyl amino ethyl) glycin hydrochloride). 名古屋医 学 (J. Nagoya Med. Assoc.), 82, 737, 1960.

392 佐々木正五, 大西信彦, 前田良三 (Sasaki, S., Onishi, N. and Maeda, R.): 無菌動物の取扱い方 1 (Application of germfree animals to medicine I). 感染症学誌(J. Jap. Assoc. Inf. Dis.), 45, 450, 1971.

393 佐々木正五, 大西信彦, 前田良三 (Sasaki, S., Onishi, N. and Maeda, R.) : 無菌動物の取扱い 方 2 (Application of germfree animals to medicine II). 感染症学誌 (J. Jap. Assoc. Inf. Dis.), 45, 494, 1971.

394 佐々木正五, 大西信彦, 前田良三 (Sasaki, S., Onishi, N. and Maeda, R.) : 無菌動物とその実験 装置. 腸内感染研究会編感染モデルの組み方, 近 代出版, 東京 (1973) (Germfree animals and experimentation apparatus. In Models for Experimental Infection, Kindai-Shuppan, Tokyo).

395 Savage, R. M. : Experiments on the sterilizing effects of mixtures of air and steam and of superheated steam. Quart. J. Pharm., 10, 451, 1937.

396 Scher, S., Collins, G. R. and Weisbroth, S. $\mathrm{H}$.: The establishment of a specific-pathogen- 
free rabbit breeding colony I Procedures for establishment and maintenance. Lab. Anim. Care, 19, 610, 1969.

397 Schley, D. G., Hoffman, R. K. and Phillips, C. R. : Simple improved chambers for gas sterilization with ethylene oxide. Appl. Microb., 8, 15, 1960.

398 Schmidt, A. R.: Some recent developments in gnotobiotic technology. Lab. Anim. Care, 13 (Part 2), 633, 1963.

399 Schneider, H. A. and Collins, G. R.: Successful prevention of infantile diarrhea of mice during an epizootic by means of a new filter cage unopened from birth to weaning. Lab. Anim. Care, 14, 334, 1963.

400 Seibert, K. and Pollard, M. : A simple method for skin grafting in germfree mice. Lab. Anim. Sci., 23, 256, 1973.

401 Seidle, C. S. and Armstrong, T. S. : Ethylene oxide treatment in laboratory animal feed for the control of Escherichia coli. Med. Bull., 28, 196, 1971.

402 Sexton, R. J. and Henson, E. V.: Dermatological injuries by ethylene oxide. J. Indust. Hyg. Toxic., 31, 297, 1949.

403 Sexton, R. J. and Henson, E. V.: Experimental ethylene oxide human skin injuries. Arch. Indust. Hyg. Occup. Med., 2, 549, 1950.

404 Shadomy, S., Ginsberg, M. K. and LaConte, M. : Evaluations of a patient isolator system I Evaluations of subsystems and procedures for sterilization and concurrent sanitation. Arch. Environ. Hlth, 11, 183, 1965.

405 Shadomy, S., Ginsberg, M. K. and Zeiger, E. : Evaluations of a patient isolator system II Distribution profiles of patient microflora during prolonged isolator confinement. Arch. Environ. Hlth, 11, 191, 1965.

406 Shafik, A. and Khinskin, L. : Determination of ethylene oxide and methods of its recovery from fumigated substances. J. Sci. Food Agric., 1, 71, 1950.

407 Sharman, G. A., Jones, A. G. and Denerly, R. : A pig herd established by hysterectomy II Health and performance. Res. Vet. Sci., 12, 65, 1971.

408 Sheffy, B. F., Baker, J. A. and Gillespie, J. H. :
A disease-free colony of dogs. Proc. Anim. Care Panel, 11, 208, 1961.

409

芝崎勲 (Shibasaki，I.) : 食品のガス殺菌に関する 研究 第3 報 食品殺菌剤としての $\beta$ プロピオラクト ンの利用 (Studies on the sterilization of food using gaseous drugs III Utilization of $\beta$-propiolactone as a food sterilant). 醗工(J. Ferment. Tech.), 43, 487, 1965.

410 芝崎勲 (Shibasaki, I.) : エチレンオキサイドガス 滅菌の得失について (Characteristic of ethylene oxide gaseous sterilization). 医器誌(J. Jap. Med. Instruments), 43, 277, 1973.

411 Short, D. J. : Sterilization and disinfection. In The I. A. T. Manual of Laboratory Animal Practice and Techniques, 2nd ed., edited by Short \& Woodnott. Crosby Lockwood, London (1969).

412 Slater, G. M. and Anastor, B. J.: The establishment of a defined hamster colony utilizing gnotobiotic techniques. In Germfree Research Biological Effect of Gnotobiotic Environments, edited by Heneghan. Academic Press, N. Y. \& London (1973).

413 Smith, C. J. and Kelleher, P. C. : A method for intragastric feeding of neonatal rats. Lab. Anim. Sci., 23, 682, 1973.

414 Smith, C. K. : Rearing gnotobiotic (germfree) goats and lambs. In Conference on Application of Caesarean-Derived Animals to Disease Control in Livestock and Laboratory Animal Production (1961).

415 Soares, J. H., Liffe, E. C. and Lareen, R. K. : Neonatal lambs in gnotobiotic environment. J. Anim. Sci., 31, 737, 1970.

416 Spiegel, A.: Sterilization of food, bedding and other materials. Food Cosmet. Toxic., 3, 57, 1965.

417 Spiner, D. R. and Hoffman, R. K. : Methods of disinfecting large enclosures with beta-propiolactone vapor. Appl. Microb., 8, 152, 1960.

418 Srinivas, H., Ananthaswamy, H. N., Vakil, U. K. and Sreenivasan, A. : Effect of gamma radiation on wheat proteins. J. Food Sci., 37, 715, 1972.

419 Stepankova, R., Klepalova, J. and Kruml, J. : Rearing of germfree rabbits. Folia Microb., 17, 505, 1972. 
420 塈見幸子 (Sumi, Y.)：ラットについての無菌人工 強制哺育之無菌繁殖の研究 (Studies on germfree hand-forced feeding and germfree reproduction in rats). 栄養と食糧 (J. Jap. Soc. Food Nutr.), 23, 51, 1970.

421 Švbáová-Stronová, M.: The fall in amino acid content on heating of protein. Nahrung, 15, 545, 1971.

422 Syukuda, Y., Fujii, S. and Shibuki, M. : Establishment of a new colony of germfree mice by hand-feeding. Exp. Anim.(実験動物), 22 (Suppl), 1973.

423 Sykes, G. : Disinfection and Sterilization, 2nd ed. E. \& F. N. Spon, London (1965).

424 Tajima, M., Sekiguchi, N. and Fujimaki, M. : The amino acid content in gamma-irradiated rice. Agric. Biol. Chem., 34, 319, 1970.

425 Talalay, P. and Takano, G. M. V.: Apparatus for tube-feeding rats. J. Lab. Clin. Med., 40, 486, 1952.

426 田波潤一郎 (Tanami, J.) : 無菌動物に関する研究 (Studies on germfree animals). 千葉医会誌 (J. Chiba Med. Soc.), 35, 1, 1959.

427 田波潤一郎 (Tanami, J.). : ビニール無菌飼育装置 と無菌動物に関する 2,3 の問題について (Germfree animals and germfree rearing apparatus I). モダンメディア (Modern Media), 7, 206, 1961.

428 田波潤一郎 (Tanami, J.) : ビニール無菌飼育装置 と無菌動物に 関する 2,3 の問題について (その II) (Germfree animals and germfree rearing apparatus II). モダンメディア(Modern Media), 7, 259, 1961.

429 田波潤一郎 (Tanami，J.) : ビニール無菌飼育装置 と無菌動物に関する 2,3 の問題について(その III) (Germfree animals and germfree rearing apparatus III). モダンメディア(Modern Media), 7, 371, 1961.

430 田波潤一郎 (Tanami, J.) : 無菌動物とノートバイ オティック動物 (Germfree and gnotobiotic animals). 化学と生物(Kagaku to Seibutsu), 2, 150, 1964.

431 Tanami, J. and Hirano, H. (田波潤一郎, 平野 英男) : Germfree hatching cage, a modification of sterile supply drum (無菌ヒナ餒化ケージ). Bull. Exp. Anim. (実験動物), 16, 99, 1967.

432 Tanami, J. and Hirano, H.: Germfree hatching cage: A modification of sterile supply drum.
In Technology in Germfree and Gnotobiotic Life Research, edited by Miyakawa \& Wostmann. Academic Press of Japan, Tokyo (1969).

433 田波潤一郎，小林茂樹，斉藤美恵，長島幸一, 小 林俊憲, 漆原昌人, 斉藤裕, 矢野三男 (Tanami, J., Kobayashi, S., Saito, M., Nagashima, K., Kobayashi, T., Urushibara, M., Saito, H. and Yano, M.) : 無菌動物飼育装置運転の標準操作一 一ビニールアイソレーター用い方のコッー ( $\mathrm{A}$ standard procedure of germfree rearing). モダ ンメディア (Modern Media), 14, 162, 1968.

434 田波潤一郎, 野村達次, 西川巂吉 (Tanami, J., Nomura, T. and Nishikawa, S.) : ビニールアイ ソレーターの作製について (Preparation of vinyl isolator for SPF animals). 実験動物(Bull. Exp. Anim.), 12, 8, 1963.

435 田波潤一郎, 塚田悦男, 若新政史, 斉藤裕, 田波男 也, 小林茂樹, 臼井久夫 (Tanami, J, Tsukada, Y., Wakashin, M., Saito, H., Tanami, D., Kobayashi, S. and Usui, H.) : 無菌動物に関す る研究——無菌動物 飼 育 用ビニールアイソレー ター——CStudies on germfree animals-Vinyl isolator for the rearing and use of germfree animals-). 千葉医会誌 (J. Chiba Med. Soc.), 40, 682, 1965.

436 Tang, Y. Z. : A simple feeder for rats and mice. Sci., 87, 398, 1938.

437 Tavernor, W. D., Trexler, P. C. and Vaughan, L. C.: The production of gnotobiotic piglets and calves by hysterotomy under general anaesthesia. Vet. Res., 88, 10, 1971.

438 Taylor, A. R.: Theoretical and practical considerations of germfree animals in virology. Ann. N. Y. Acad. Sci., 78, 102, 1959.

439 Thimm, H. J., Hiller, N. H. and Eichberg, J. : Simplification of the method of obtaining germfree animals. Z. Versuchstierk., 11, 381, 1969.

440 Tinsley, J. J., Bone, J. F. and Bubl, E. C. : The growth, reproduction, longevity, and histopathology of rats fed gamma-irradiated carrots. Toxic. Appl. Pharm., 16, 306, 1970.

441 戸塚耕二, 田嶋政秀, 庄司圭吾, 梅田圭司, 川嶋 浩二, 高野博幸 (Totsuka, K., Tajima, M., Shōji, K., Umeda, K., Kawashima, K. and Takano, H.) : ガンマー線照射による飼料の殺菌 (Steri- 
lization of diets by gamma irradiation). 実験 動物 (Exp. Anim.), 22, 251, 1973.

442 Townsedn, G. H. and Robinson, M. H. : Transport of laboratory animals. In The UFAW Handbook on the Care and Management of Laboratory Animals, 4th ed. Churchill Livingstone, Edinburgh \& London (1972).

443 Tregier, A. and Homburger, F. : Bacterial flora of the mouse uterus. Proc. Soc. Exp. Biol. Med., 108, 152, 1961.

444 Trexler, P. C.: Progress report on the use of plastics in germfree equipment. Proc. Anim. Care Panel, 9, 119, 1959.

445 Trexler, P. C.: The use of plastics in the design of isolator systems. Ann. N. Y. Acad. Sci., 78, 29, 1959.

446 Trexler, P. C. : Equipment for germfree and SPF animal production. In Conference on Application of Caesarean-Derived Animals to Disease Control in Livestock and Laboratory Animal Production (1961).

447 Trexler, P. C.: An isolator system for control of contamination. Lab. Anim. Care, 13 (Part 2), 572, 1963.

448 Trexler, P. C.: Germfree isolators. Sci. Am., 211 (July), 78, 1964.

449 Trexler, P. C. : Microbic contamination control. Bull. Parenteral Drug Assoc., 18, 8, 1964.

450 Trexler, P. C. : Equipment design and management II Transport of germfree animals and current developments in equipment design. In The Germfree Animal in Research, edited by Coates. Academic Press, N. Y. \& London (1968).

451 Trexler, P. C.: Gnotobiotics and animal house design. In Laboratory Animal Symposia 1 The Design and Function of Laboratory Animal Houses, edited by Hare \& O'Donoghue. Laboratory Animal Ltd., London (1968).

452 Trexler, P. C. : Microbiological isolation of large animals. Vet. Rec., 88, 15, 1971.

453 Trexler, P. C. : Gnotobiotic animals I In The UFAW Handbook on the Care and Management of Laboratory Animals, 4th ed. Churchill Livingstone, Edinburgh \& London (1972).

454 Trexler, P. C. and Barry, E. D. : Development of inexpensive germfree animal rearing equip- ment. Proc. Anim. Care Panel, 8, 75, 1958.

455 Trexler, P. C. and Pilcher, M. F. : A gauntlet isolator for hip arthroplasty. In Germfree Research Biological Effect of Gnotobiotic Environments, edited by Heneghan. Academic Press, N. Y. \& London (1973).

456 Trexler, P. C. and Reynolds, L. I. : Flexible film apparatus for the rearing and use of germfree animals. Appl. Microb., 5, 406, 1957.

457 Tsien, W. S. and Johnson, B. C. : The effect of radiation sterilization on the nutritive value of foods IV On the amino acid composition of garden peas and lima beans. J. Nutr., 68, 419, 1959.

458 Udes, H. : Untersuchungen mit halbsynthetischen Diäten bei "keimfreien" Laboratoriumstieren. Z. Versuchstierk., 13, 243, 1971.

459 Udes, H.: Anforderungen und die Ernährung definierter Versuchstiere. Berl. Münch. Tierärztl. Wschr., 84, 468, 1971.

460 Udes, H., Hiller, H. H. and Juhr, N. C. : Veränderungen der Rohproteinquantität und -qualität einer Ratten-und Mäusediät durch verschiedene Sterilisationsverfahren. Z. Versuchstierk., 13, 160, 1971.

461 Underdahl, N. R. and Young, G. A. : An improved hood for swine hysterectomies. J. Am. Vet. Med. Assoc., 131, 222, 1957.

462 Underdahl, N. R. and Young, G. A. : An isolation brooder for rearing disease-free pigs. $\mathrm{J}$. Am. Vet. Med. Assoc., 131, 279, 1957.

463 Vaissaire, J.: Les Animaux Axeniques. Vigot Frères Éditeurs, Paris (1968).

464 Valerio, D. A., Darrow, II, C. C. and Martin, D. P.: Rearing of infant simians in modified germfree isolators for oncogenic studies. Lab. Anim. Care, 20 (Part 1), 713, 1970.

465 van der Gulden, W. J. I. and van Erp, A. J. M. : The effect of peracetic acid as a disinfectant on worm eggs. Lab. Anim. Sci., 22, 225, 1972.

466 van der Waaij, D. : Downflow patient isolator for strict isolation (Organization for Health Research TNO, Netherlands).

467 van der Waaij, D. and Andreas, A. H.: Prevention of airborne contamination and crosscontamination in germfree mice by laminar 
flow. J. Hyg., Camb., 69, 83, 1971.

468

tive study of patients with acute leukemia under gnotobiotic conditions by the gnotobiotic project group of the European organization for research on treatment of cancer. In Germfree Research Biological Effect of Gnotobiotic Environment, edited by Heneghan. Academic Press, N. Y. \& London (1973).

469 van der Waaij, D., Heidt, P. J. and Wasman, O. : The evaluation of high volume ventilation in rooms for reverse isolation of patients. Ann. Rep. R. E. P., Netherlands, 202 (1972).

470 van der Waaij, D. and Sturvn, C. A.: The production of "bacteria-free" mice. Relationship between fecal flora and bacterial population of the skin. Antonie van Leeuwenhock, 37, 139, 1971.

471 van der Waaij, D., Vossen, J. M. and Altes, K. : Patient isolators designed in the Netherlands. In Germfree Research Biological Effect of Gnotobiotic Environment, edited by Heneghan. Academic Press, N. Y. \& London (1973).

472 van Hoosier, Jr., G. L., Stenback, W. A., Parker, J. C., Burke, J. G. and Trentin, J. J. : The effects of caesarean derivation and foster nursing procedures on enzootic viruses of the LSH strain of inbred hamsters. Lab. Anim. Care, 20, 232, 1970.

473 van Hoosier, Jr., G. L., Trentin, J. J., Jacqueline, S., Stephens, K., Stenback, W. A. and Parker, J. C.: Effect of caesarian-derivation, gnotobiotes foster nursing and barrier maintenance of an inbred mouse colony on enzootic virus status. Lab. Anim. Care, 16, 119, 1966.

474 Velu, H., Lepigre, A. and Bellocq, B. : Action bactéricide de l'oxyde d'ethylene à etat gazeux. Bull. Acad. Nat. Méd., 126, 62, 1942.

475 Vesley, D., Michaelsen, G. S. and Levitan, A. A. : The application of laminar flow rooms to patient isolation. Adv. Exp. Med. Biol., 3, 1, 1969.

476 Victorin, K., Hellström, K. G. and Rylander, R.: Redox potential measurements for determining the disinfecting power of chlorinated water. J. Hyg., Camb., 70, 313, 1972.
477 Vossen, J. M. and van der Waaij, D. : Reverse isolation in bone marrow transplantation: Ultra-clean room compared with laminar flow technique I Isolation systems. Europ. J. Clin. Biol. Res., 17, 457, 1972.

478 Vossen, J. M. and van der Waaij, D. : Reverse isolation in bone marrow transplantation: Ultra-clean room compared with laminar flow technique II Microbiological and clinical results. Europ. J. Clin. Biol. Res., 17, 564, 1972.

479 Wagner, M. : Determination of germfree status. Ann. N. Y. Acad. Sci., 78, 89, 1959.

480 Waibel, P. E., Rao, B. S., Dunkelgod, K. E., Siccardi, F. J. and Pomeroy, B. S. : A chemically defined liquid diet for the chick. J. Nutr., 88, 131, 1966.

481 Walburg, Jr., H. E., Upton, A. C., Tyndall, R. L., Harris, W. W. and Cosgrove, G. E. : Preliminary observations on spontaneous and radiation-induced leukemia in germfree mice. Proc. Soc. Exp. Biol. Med., 118, 11, 1964.

482 Warner, P.: Recent advances in sterilization. Can. Hospital, 38 (1961).

483 Waxler, G. L. : Research on rearing specific pathogen free and germfree swine. In Conference on Application of Caesarean-Derived Animals to Disease Control in Livestock and Laboratory Animal Production (1961).

484 Waxler, G. L., Schmidt, D. A. and Whitehair, C. K. : Technique for rearing gnotobiotic pigs. Am. J. Vet. Res., 27, 300, 1966.

485 Waxler, G. L. and Whitehair, C. K. : Germfree swine in biomedical research. In Swine in Biomedical Research. Tryn Printing, Washington (1966).

486 Wedum, A. G., Hanel, Jr., E. and Phillips, G. B. : Ultraviolet sterilization in microbiological laboratories. Publ. Hlth Rep., 71, 331, 1956.

487 Wellman, G. : Erste eigene Erfahrungen über die sterile Geburt von Ferkeln und ihre Aufzucht ohne mütterliche Antikörper krankheitserregerfrei. Zbl. Bakt. I. Orig., 183, 390, 1961.

488 Wells, W. F. : Airborne Contagion and Air Hygiene. An Ecological Study of Droplet In- 
fection. Harvard Univ. Press, Massachusetts (1955).

489 Weibroth, S. H. and Scher, S.: The establishment of a SPF rabbit breeding colony II Monitoring for disease and health statistics. Lab. Anim. Care, 19, 795, 1969.

490 Wescott, R. B. and Gardner, J. A. : Apparatus and method for the steam sterilization on food for germfree laboratory animals: An investigation of the practical application of gnotobiotic technology to the improvement of breeding colonies (1962).

491 Whitehair, C. K. : Animal production and rearing II Large mammals. In The Germfree Animal in Research, edited by Coates. Academic Press, N. Y. \& London (1968).

492 Whitehair, C. K., Eaton, B. G., Starkey, A. L. and Calverley, J. L. : Round table discussion on rearing gnotobiotic swine. Lab. Anim. Care, 13 (Part 2), 673, 1963.

493 Whitehair, C. K. and Waxler, G. L. : Rearing cesarotomy-derived swine in controlled environments-Present status. Lab. Anim. Care, 13 (Part 2), 655, 1963.

494 Whitehair, C. K., Waxler, G. L., Trexler, P. C. and Hakes, R. F.: Techniques for rearing germfree pigs. J. Anim. Sci., 20, 955, 1961.

495 Williams, F. P., Christie, R. J., Johnson, D. J. and Whitney, R. A.: A new autoclave system for sterilizing vitamin-fortified commercial rodent diets with lower nutrient loss. Lab. Anim. Care, 18, 195, 1968.

496 Wilson, A. T. and Bruno, P.: The sterilization of bacteriological madia and other fluids with ethylene oxide. J. Exp. Med., 91, 449, 1950.

497 Wilson, R., Bealmear, M. and Sjodin, K. : A technique for thymectomizing germfree mice. J. Appl. Phys., 21, 279, 1966.

498 Wilson, R., South, M. A., Malinak, L. R., Lawton, A. R., Cooper, M. D. and Flowers, Jr., C. E.: A simplified plastic flexible film isolator system for the germfree delivery and maintenance of infants with immune deficiency. In Germfree Research Biological Effect of Gnotobiotic Environment, edited by Heneghan. Academic Press, N. Y. \& London (1973).
499 Windmueller, H. G. and Ackerman, C. J. : Alterations in the nutritive value of casein by exposure to ethylene oxide. J. Nutr., 60, 527, 1956.

500 Wiseman, R. F.: Gnotobiotics and germfree animal. Biosci., 15, 187, 1965.

501 Wold, J. K., Kahn, R. and Midvedt, T. : Inte stinal glycoproteins of germfree rats. Chemical composition of intestinal and fecal mucus from germfree rats fed a chemically defined diet. Acta Path. Microb. Scand., 79, 525, 1971.

502 Wolfe, L., Griesemer, R. and Rohovsky, M. : Germfree cynomologus monkeys. Lab. Anim. Care, 16, 364, 1966.

503 Woodnott, D. P. : A simple technique for passing an oesophageal tube in the rat. J. Anim. Tech. Assoc., 12, 59, 1961.

504 Wostmann, B. S.: Nutrition of the germfree mammal. Ann. N. Y. Acad. Sci., 79, 175, 1959.

505 Wostmann, B. S. : Gnotobiotes: Standards and guidelines for the breeding, care, and management of laboratory animals. ILAR, Nat. Res. Council (1970).

506 Wostmann, B. S. and Kellogg, T. F. : Purified starch-casein diet for nutritional research with germfree rats. Lab. Anim. Care, 17, 589, 1967.

507 Wostmann, B. S., Olson, G. B. and Pleasants, J. R.: Serum proteins of germfree rats fed water-soluble diets. Nature, 206, 1056, 1965.

508 Wostmann, B. S. and Pleasants, J. R. : Rearing of germfree rabbits. Proc. Anim. Care Panel, 9, 47, 1959.

509 Wostmann, B. S. and Pleasants, J. R. : Diet and diet sterilization. In Technology in Germfree and Gnotobiotic Life Research, edited by Miyakawa \& Wostmann. Academic Press of Japan, Tokyo (1969).

510 Wostmann, B. S., Pleasants, J. R., Bealmear, P. and Kincade, P. W.: Serum protein and lymphoid tissues in germfree mice fed a chemically defined, water soluble, low molecular weight diet. Immunol., 19, 443, 1970.

511 Wright, I.: Transmission of Toxoplasma gondii across the guinea pig placenta. Lab. Anim., 6, 169, 1972 . 
512 Wright, W. H., Phillips, B. P. and Newton, W. L. : Germfree animal research at the National Institutes of Health. Recent Prog. Microb., 7, 314, 1959.

513 Yale, C. E. : The cuboidal sterilizing chamber. Lab. Anim. Care, 18, 500, 1968.

514 Yale, C. E. : An isolation system for the germfree dog. Lab. Anim. Care, 19, 103, 1969.

515 Yale, C. E. : A lightweight pneumatically sealing metal door for germfree isolators. Lab. Anim. Sci., 21, 588, 1971.

516 Yale, C. E. : A combination sterilizing chamber and transfer and housing isolator for use in gnotobiotic laboratories. Lab. Anim. Sci., 23, 885, 1973.

517 Yale, C. E. and Linsley, J. G. : A large efficient isolator for holding germfree rats. Lab. Anim. Care, 20 (Part 1), 749, 1970.

518 Yale, C. E., Linsley, J. G. and Anderson, L. C. : Heat sterilization of water in a large open vessel. Appl. Microb., 16, 609, 1968.

519 Yale, C. E. and Vivek, A. R. : Air filters for germfree isolators. Appl. Microb., 16, 1650, 1968.

520 Yamanaka, M., Saito, M., Yamauchi, C. and Nomura, T. (山中聖敬, 斉藤宗雄, 山内忠平, 野 村達次) : Influence of autoclaving of diets on digestibility of nutrients and nitrogen retention in conventional mice (オートクレーブによ る飼料の滅菌がそれの消化率および 窒素蓄積にお よぼす影響). Exp. Anim. (実験動物)， 22，5， 1973.

521 山田一正, 竹内峰子, 比良愛子, 佐光富士男, 今村 一夫, 植谷忠昭 (Yamada, K., Takeuchi, M., Hira, A., Sako, F., Imamura, K. and Uetani, T.) : 無菌環境下に打ける急性白血病の化学療法 (Chemotherapy of acute leukemia in an isolator system). 空気清浄 (Jap. Air. Cleaning Assoc.), 11 (2), 11, 1973.

522 山田幸彦 (Yamada, Y.) : 2, 3 両性界面活性剂の 殺菌, 消毒効果之物理化学的性質の関連性につい $\tau$ (Possible reactions between disinfectant action and physico-chemical properties of some amphoteric surfactants). 歯科医学 (J. Osaka Odont. Soc.), 31, 506, 1968.

523 吉田勉 (Yoshida, T.) : 飼料の滅菌と滅菌飼料に よる飼育 (Sterilization of feed and breeding by sterilized diet). 実験動物 (Exp. Anim.)， 20, 80, 1971.

524 吉田勉 (Yoshida, T.) : 無菌ウサギの人工哺育に ついて (Hand rearing of the germfree rabbit). 実験動物 (Exp. Anim.), 21, 1, 1972.

525 吉田勉 (Yoshida, T.) : 無菌動物の飼料問題 (Diets for germfree animals). 畜産の研究 (Anim. Husbandry), 26, 225, 1972.

526 吉田勉 (Yoshida, T.) : 無菌動物用飼料の滅菌に よる成分変化について (On the chemical decomposition of the diets for germfree animals during sterilization). 立川短大紀要 (J. Tachikawa Col. Tokyo), 5, 17, 1972.

527 吉田勉 (Yoshida, T.) : 無菌動物の栄養 的 特 徵 について(Nutritional characteristics of the germfree animal). 日畜会報 (Jap. J. Zootech. Sci.), 43, 1, 1972.

528 吉田勉 (Yoshida, T.) : 無菌動物の生産と応用 (Production and industrial application of germfree animals). 科学飼料(Synthetic Feeds), 18, 377, 1973.

529 吉田勉, 平野敬子, 神薗稔, 倉益茂実 (Yoshida, T., Hirano, K., Kamizono, M. and Kuramasu, S.)：無菌ウズラの栄養に関する研究 (第 1 報) 成 長および飼料効率について (Nutrition of germfree Japanese quail, Coturnix coturnix japoni$c a$, I On the growth and feed efficiency). 栄養 と食糧 (J. Jap. Soc. Food Nutr.), 22, 208, 1969.

530 吉田勉, 平野敬子, 神䄇稔, 倉益茂実 (Yoshida, T., Hirano, K., Kamizono, M. and Kuramasu, S.) : 無菌ウズラの栄養に関する研究 (第 2 報) 成 長中の $\mathrm{N}, \mathrm{Ca}, \mathrm{Mg}$ 执よび $\mathrm{P}$ の蓄積率について (Nutrition of germfree Japanese quail, Coturnix coturnix japonica, II $\mathrm{On} \mathrm{N}, \mathrm{Ca}, \mathrm{Mg}$ and $\mathrm{P}$ during the growth). 栄養と食糧 (J. Jap. Soc. Food Nutr.), 22, 213, 1969.

531 Yoshida, T., Pleasants, J. R., Reddy, B. S. and Wostmann, B. S. : Efficiency of digestion in germfree and conventional rabbits. Brit. J. Nutr., 22, 723, 1968.

532 Yoshida, T., Pleasants, J. R., Reddy, B. S. and Wostmann, B. S. : Amino acid composition of cecal contents and feces in germfree and conventional rabbits. J. Nutr., 101, 1423, 1971.

533 Young, G. A. SPF swine. Adv. Vet. Sci., 9, 61, 1964. 
534 Young, G. A. and Underdahl, N. R. : Isolation units for growing baby pigs without colostrum. Am. J. Vet. Res., 14, 571, 1953.

535 Young, G. A., Underdahl, N. R. and Hinz, R. W. : Procurement of baby pigs by hysterectomy. Am. J. Vet. Res., 16, 123, 1955.

536 Zimmerman, D. R. and Wostmann, B. S. :
Vitamin stability in diets sterilized for germfree animals. J. Nutr., 79, 318, 1963.

537 Znamirowski, R., McDonald, S. and Roy, T. E. : The efficiency of an ethylene oxide sterilizer in hospital practice. Can. Med. Assoc. J., 83, 1004, 1960. 